\title{
Il duomo di Orvieto. Rilievo integrato e modellazione
}

\author{
Roberto Barni \\ Carlo Bianchini \\ Carlo Inglese
}

\begin{abstract}
L'articolo presenta i risultati di uno studio condotto sul duomo di Orvieto attraverso la creazione di modelli realizzati a partire da processi di Structure from Motion, attraverso modellazione parametrica poligonale. I risultati presentati, oltre che analizzare le differenti metodologie di modellazione impiegate, giungono ad una ricostruzione diacronica della fabbrica del duomo, con particolare attenzione agli elementi materici e agli apparati decorativi di una delle cappelle laterali.
\end{abstract}

Parole chiave

rilievo SFM, duomo di Orvieto, modellazione parametrica poligonale,Virtual Reality.

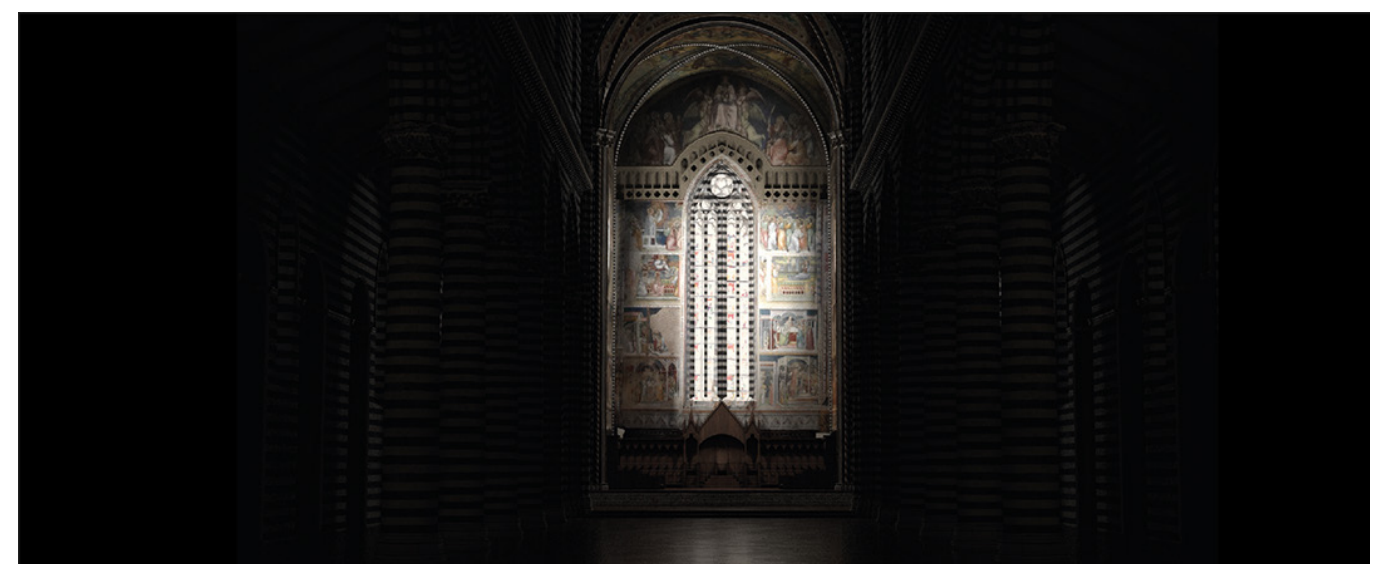




\section{Introduzione}

Simbolo della città di Orvieto, il duomo è una delle principali e più importanti cattedrali del gotico italiano. L'inizio dei lavori per la sua costruzione viene fatto risalire al 1290, quando papa Niccolò IV pose la prima pietra di fondazione [I].

L'impianto originario del duomo doveva presentare una forma basilicale a tre navate con transetto. La pianta recava sei cappelle semicircolari per lato e un'abside innestata sul transetto, anch'essa semicircolare (fig. Ia).

A partire dal 1308 Lorenzo Maitani è documentato nel cantiere con la carica di universalis capud magister. A lui sono attribuiti il progetto della facciata cosiddetta tricuspidale, nonché la realizzazione di tre coppie di speroni rampanti paralleli ai muri della tribuna e delle due grandi cappelle (fig. Ib).

Sfruttando le giaciture di queste opere di consolidamento, negli anni successivi verranno realizzati degli ambienti che stravolgeranno la spazialità originaria del duomo, definendone l'aspetto attuale: la nuova tribuna (1328-1335), la cappella del Corporale (|350- | 356) e la cappella Nova (|406-|444) detta anche della Madonna di San Brizio (fig. Ic).

\section{Approccio metodologico}

La conoscenza di un monumento nella sua configurazione spaziale e nel suo rapporto tra le parti è l'obiettivo preminente delle operazioni di rilievo: essa è resa possibile attraverso la lettura critica del dato e l'integrazione delle informazioni, sistematizzate secondo criteri condivisi tra gli operatori del settore del rilievo e quelli di altri settori. La costruzione di una copia digitale dell'oggetto investigato consente di ripercorrere lo stesso processo di ricerca che, partendo dalla fase di scavo e, procedendo per successivi livelli stratigrafici, arriva all'interpretazione del contesto e delle sue trasformazioni.

Nel modello digitale questo processo di indagine perde il limite temporale e spaziale: infatti, il modello è ispezionabile sempre e, soprattutto, sempre in maniera reversibile; lo stesso modello, inoltre, può essere discretizzato considerando singolarmente solo porzioni e livelli, corrispondenti a fasi storiche o stratigrafie utili alla comprensione del dato. Tale peculiarità del modello digitale consente di visualizzare il monumento secondo parametri e percorsi di indagine più efficaci di quelli sperimentabili in loco.

Le possibilità dello strumento digitale sono determinanti per il raggiungimento degli obiettivi conoscitivi: nell'ambito delle indagini svolte nel duomo di Orvieto risultava necessario acquisire dati di varia natura in un periodo di tempo molto limitato, compatibile con le esigenze della tutela e della sicurezza del sito. L'assetto del contesto di indagine ha suggerito

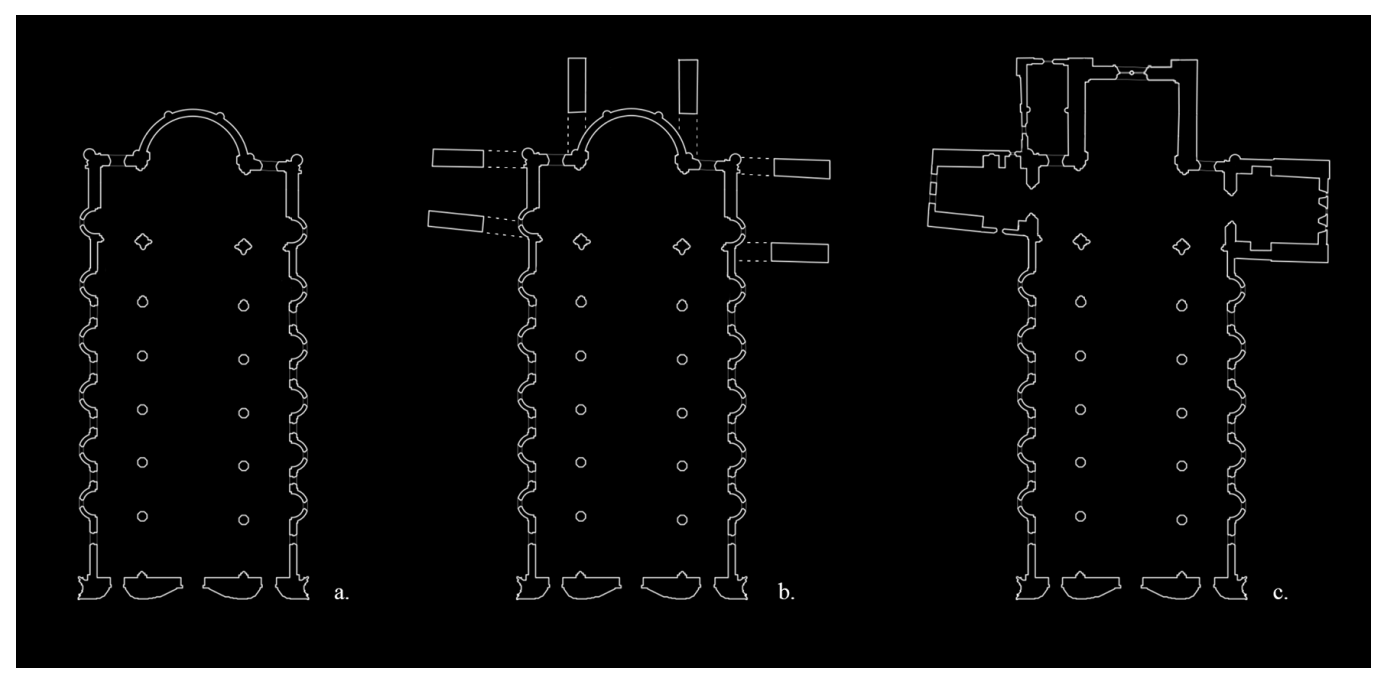


la metodologia di rilievo da seguire: la limitata accessibilità, dal punto di vista temporale, e la particolare configurazione spaziale del duomo ha reso fondamentale l'attuazione di sistemi di acquisizione per SFM (Structure from Motion) che consentissero di coprire l'area nella sua interezza e che producessero un modello virtuale facile da leggere e metricamente attendibile.

\section{Progetto di rilievo e restituzione dei dati acquisiti}

In tale impegnativo contesto si è deciso di impiegare processi di SPM, non solo per economicità e trasportabilità, ma anche per risolvere il problema legato alla staticità del set di acquisizione imposta dal laser scanner: la fotocamera, utilizzata come strumento di acquisizione dati, permette una notevole versatilità nell'organizzazione della campagna di rilievo ed ha consentito la suddivisione dell'intero monumento in diversi set fotografici.

L'elaborazione dei dati è stata effettuata attraverso l'uso del software Agisoft Metashape [2]. Basato sulla più recente tecnologia di ricostruzione multi-view 3D, tale programma permette di acquisire dati metrici di un oggetto attraverso l'analisi di fotogrammi, che devono avere una certa percentuale di sovrapposizione (overlapping), generalmente non inferiore al 60\%. La procedura di generazione del modello 3D, a partire dall'acquisizione del materiale fotografico, consta di quattro fasi principali.

La prima fase consiste nell'importazione all'interno del programma e nel successivo allineamento delle foto acquisite: metashape analizza i punti comuni tra le foto, determina la posizione della fotocamera per ogni immagine e ne restituisce l'allineamento. Come risultato genera una prima nuvola sparsa di punti dell'intero ambiente fotografato (fig. 2a).

Per ottimizzare il lavoro si circoscrive la scena con una Bounding Box che delimita l'elaborazione all'oggetto di interesse, rendendo possibile la creazione di una nuvola densa di punti, ottenuta dal calcolo delle misure rilevate dalla superficie dell'oggetto fotografato. Già in questa fase si percepisce nella sua interezza l'oggetto di studio, che non è ancora un elemento lavorabile per quel che riguarda la modellazione poligonale (fig. 2b).

La terza fase è la costruzione della mesh del modello, cioè la rete di poligoni che compone la geometria del solido, ricostruzione basata sull'algoritmo Arbitrary, applicabile a qualsiasi tipo di oggetto (fig. 2c). Dopo aver generato la Mesh, si possono eseguire su quest'ultima delle correzioni, come la sua decimazione, la rimozione di componenti staccate, la chiusura di buchi ecc. direttamente all'interno del programma.

Per rendere l'aspetto finale dell'oggetto occorre generare la texture: un'immagine bidimensionale in formato raster che viene riprodotta sulle facce del modello poligonale tridimensionale (fig. 2d). La geometria ricostruita, quindi, potrà essere utilizzata per la generazione di ortofoto.

Per spiegare questo processo è stata utilizzata la statua di San Rocco (fig. 2), realizzata nel I593 dallo scultore Fabiano Toti per la controfacciata del duomo di Orvieto. La metodo-

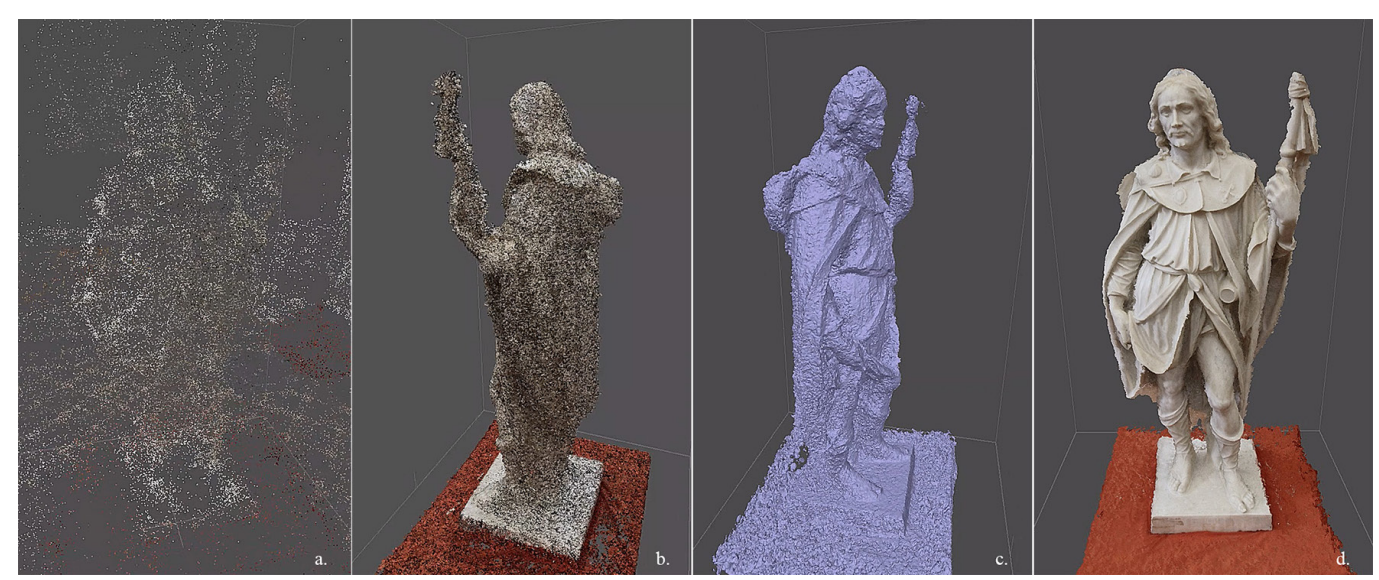


logia di acquisizione dati precedentemente descritta può essere applicata tanto a oggetti dalle dimensioni contenute - come la statua suddetta, alta appena I,90 m - quanto a edifici complessi dalle dimensioni considerevoli, come l'intero duomo (fig. 3).

Tale tecnica porta con sé alcune limitazioni legate alla mancanza di dato (elementi non fotografabili), nonché errori dovuti al procedimento di acquisizione dati (operatore e mezzo utilizzato) o all'elaborazione degli stessi (imprecisioni del modello) [3]. Da studi precedentemente condotti [4] si può ipotizzare che, per edifici dell'ordine di grandezza dell'intera fabbrica presa in esame, l'errore possa essere di $8-10 \mathrm{~cm}$. Ovviamente tale errore può essere accettabile per le finalità che tale studio si è posto: quelle della valorizzazione; ma non lo sarebbe altrettanto se l'intento fosse quello del monitoraggio strutturale.

\section{Modellazione}

II modello numerico elaborato dal programma presenta un'infinità di poligoni che ne rendono limitata la lavorabilità dal punto di vista della modellazione (fig. 4). Perciò è necessario semplificarlo re-topologizzandolo, realizzandone uno matematico, anche detto low poly, costituito da pochi poligoni (fig. 5).

Nel caso del duomo di Orvieto è stata utilizzata una modellazione detta poligonale, che si differenzia da quella nurbs per l'algoritmo che sta alla base del processo di creazione del modello.

La modellazione nurbs - Non Uniform Rational Be Spline - si basa sulla creazione di curve di Bezier e spline, che permettono un controllo perfetto delle superfici che si vanno a generare. La modellazione poligonale, al contrario, si basa sull'approssimazione - più o meno verosimile - degli oggetti reali, permettendo al contempo una gestione più flessibile della geometria del modello.

Ad esempio, in un software come Rhinoceros, che si basa sulla modellazione nurbs, un quadrato è il risultato delle quattro curve che lo delimitano e solo queste curve saranno modificabili. Mentre nei software di modellazione poligonale, come Cinema 4D o Modo, un quadrato è l'esito della combinazione di vertici (vertex), spigoli (edge) e facce (poligon): tutti e tre questi elementi saranno modificabili.

Un programma di modellazione parametrica poligonale come Modo (utilizzato, assieme a Cinema 4D per restituire tridimensionalmente il duomo di Orvieto) permette di partire da solidi primari, come il cubo, il cilindro o la sfera, per poi modificarli, selezionando di volta in volta i vertici, gli spigoli o le facce, fino a creare forme complesse [5].

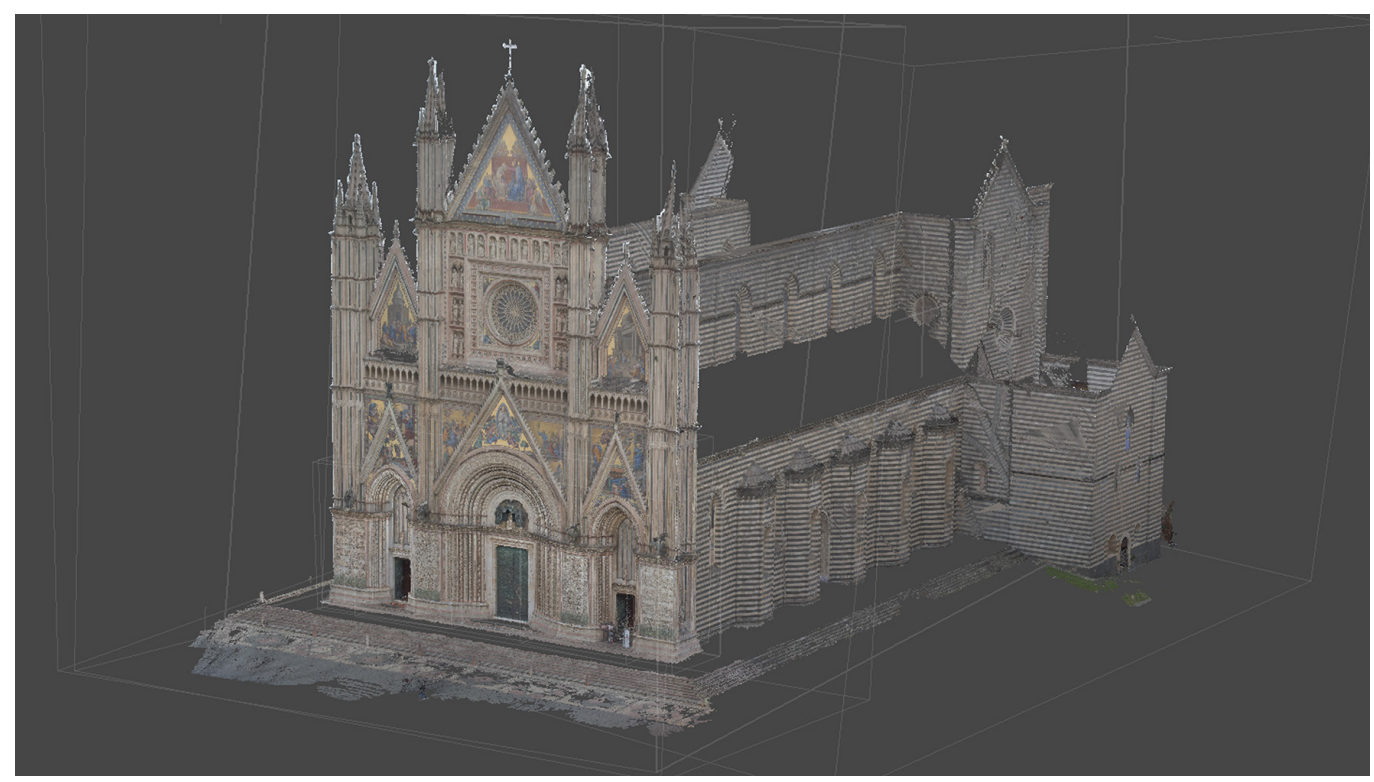




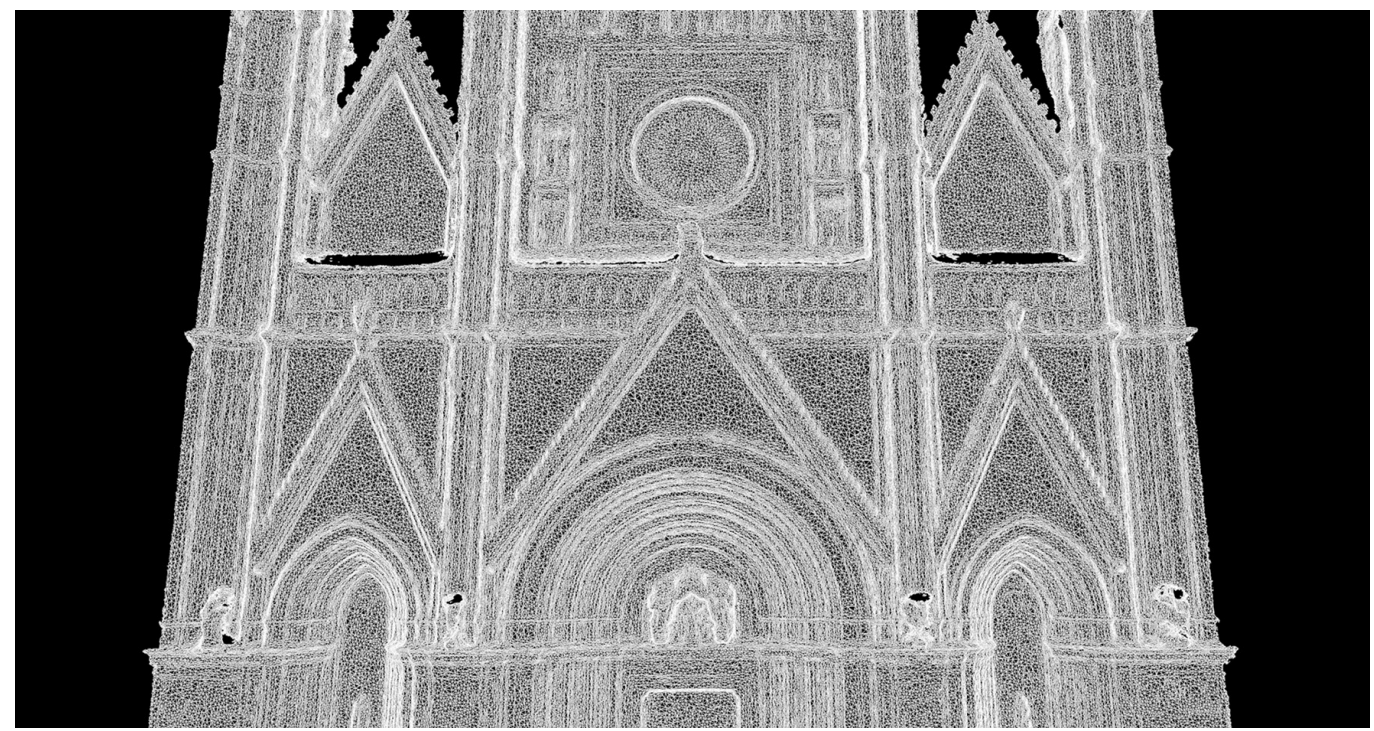

I processi che coinvolgono la realizzazione di un'immagine 3D non si esauriscono con la modellazione dell'oggetto, ma implicano altri essenziali passaggi, quali l'UV mapping, il texturing, il lighting e il rendering.

Passaggio fondamentale per poi arrivare all'immagine finale è la mappatura, o UV mapping: geometrie complesse, come le colonne tortili in facciata, devono essere sviluppate su un piano tramite l'unwrapping. A questo punto ogni vertice dell'oggetto tridimensionale disporrà di un set di coordinate bidimensionali condiviso con l'immagine, che potrà essere quindi associata alle sue facce, risultando visibile nello spazio 3D. Per controllare la qualità dell'UV mapping creata, è buona norma usare una texture di controllo detta checker, che permette di verificare - attraverso un'immagine raster formata da una griglia a maglia quadrata di numeri e colori - se la proiezione dell'unwrapping è corretta (fig. 6a).

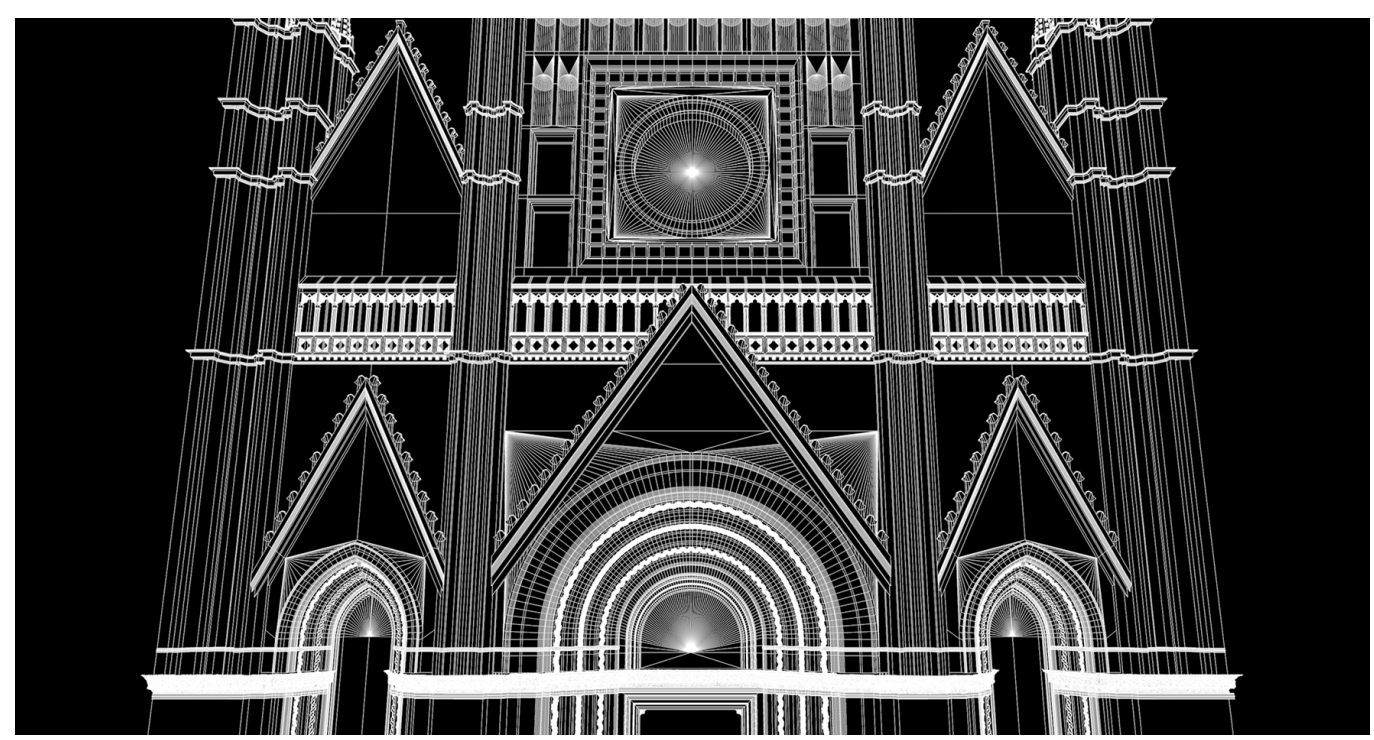


Una volta concluso l'unwrapping, si può procedere con il texturing, che permette di proiettare una o più texture - precedentemente realizzate con programmi di fotoritocco, quali Adobe Photoshop - sulla superficie di un modello 3D, utilizzando le coordinate UV (fig. 6b). Essa rende il modello più dettagliato e realistico.

Per concludere il workflow l'ultimo passaggio è il rendering (in questo caso realizzato con l'engine Corona Renderer per Cinema 4D), processo attraverso il quale si genera dalla scena 3D un'immagine 2D. II bilanciamento delle luci, la resa dei materiali e il taglio fotografico della scena incidono molto sulla buona riuscita di un render realistico $($ figg. 7,8$)$.

Per perseguire l'intento della valorizzazione del bene si è optato per l'utilizzo di dispositivi che permettono l'immersività totale all'interno della scena, attraverso render panoramici in formato equirettangolare, visibili a $360^{\circ}$ grazie a visori per la VR, fruibili dall'utente finale (fig. 9).

\section{Conclusioni: conoscenza, valorizzazione e divulgazione}

La restituzione dell'immagine mira, inoltre, alla divulgazione e alla conoscenza della fase costruttiva cinquecentesca, ormai perduta e qui mantenuta in bianco e nero (fig. I0).

Tra il I556 e il I575, infatti, vengono costruite dieci cappelle nelle edicole laterali e due all'interno della controfacciata, ognuna costituita da un altare, sormontato da una grande pala incorniciata da stucchi, marmi, grottesche e affreschi [6]. Tale ciclo decorativo, fortemente ancorato ai principi controriformistici dettati dal Concilio di Trento, è andato perduto. Tra il 1877 e il I89I, infatti, l'ing. Zampi realizza, con il supporto dello storico Luigi Fumi, un restauro di ripristino della facies medievale del monumento [7].

Il progetto che si è tentato di perseguire mira ad offrire una lettura dello spazio della fase cinquecentesca ormai perduta, impensabile da riproporre da un punto di vista materico. La ricostruzione cromatica è stata tentata solo per la terza cappella di sinistra (fig. I I) [8]. Tale risultato è stato possibile grazie ad un confronto filologico tra le foto storiche effettuate prima del restauro e le opere realizzate in quegli anni dagli stessi pittori e decoratori attivi all'interno della cattedrale.

Il ciclo più simile lo troviamo nel palazzo del cardinal Girolamo Simoncelli, a Torre San Severo, vicino Orvieto. Di questo edificio ci sono pervenute le decorazioni di tre ambienti, con temi sacri e profani, incorniciati da grottesche, opere proprio di Girolamo Muziano, Cesare

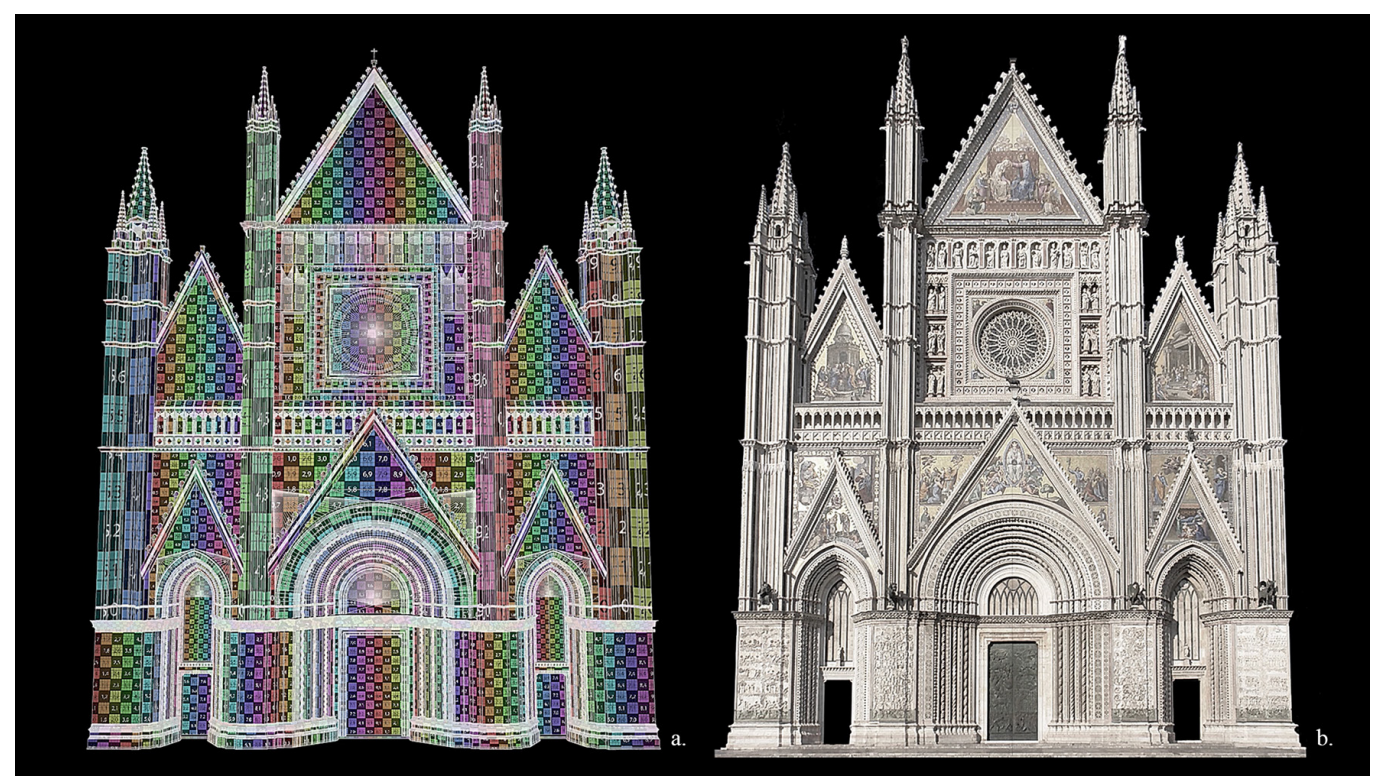




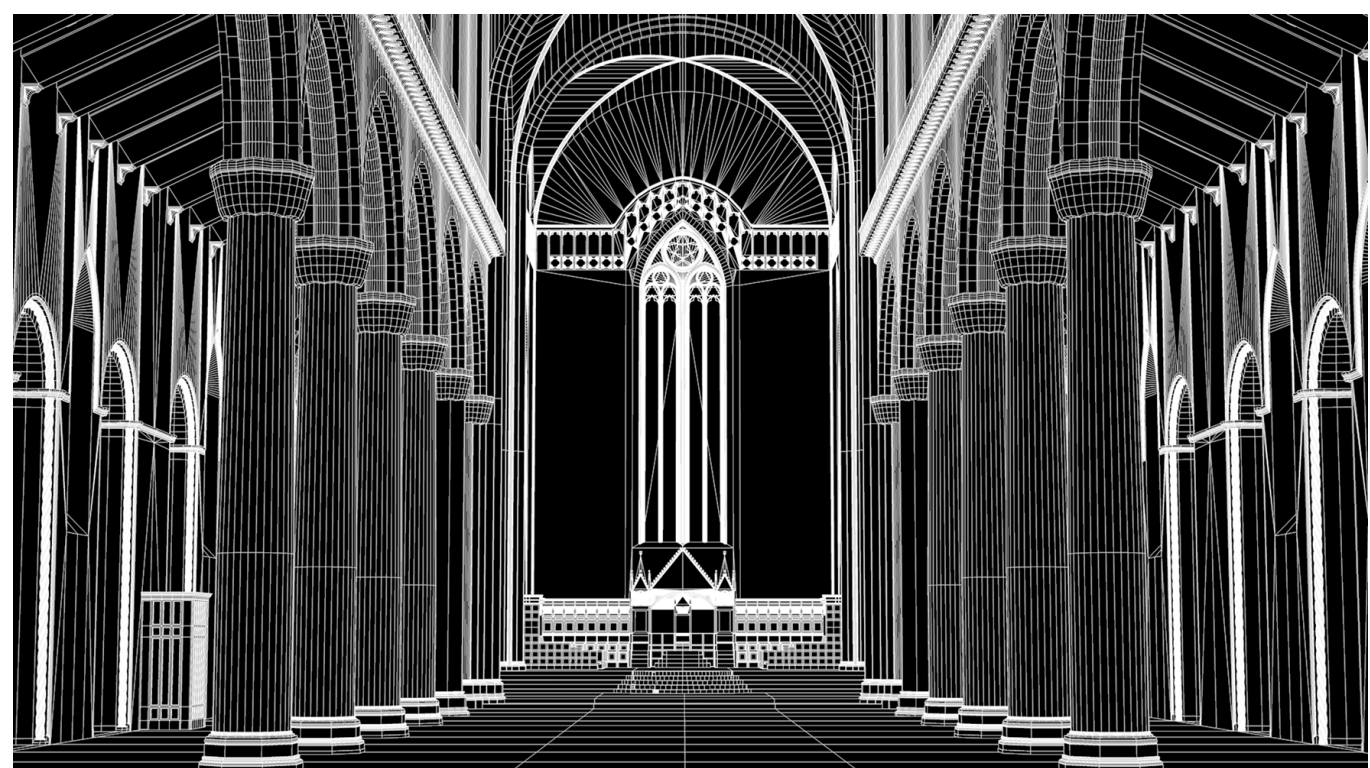

Fig. 8. Vista renderizzata

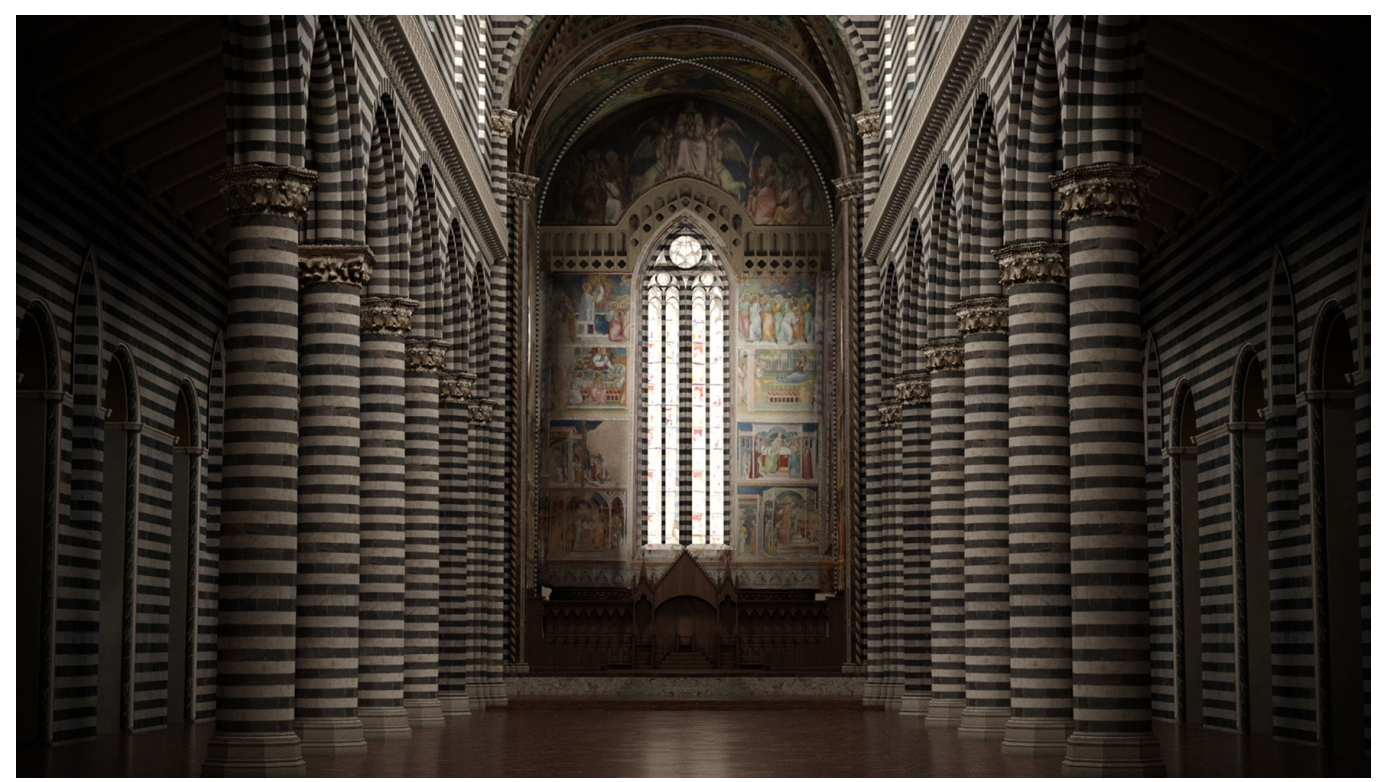


Fig. 9. Vista panoramica renderizzata in formato equirettangolare dell'interno del Duomo.

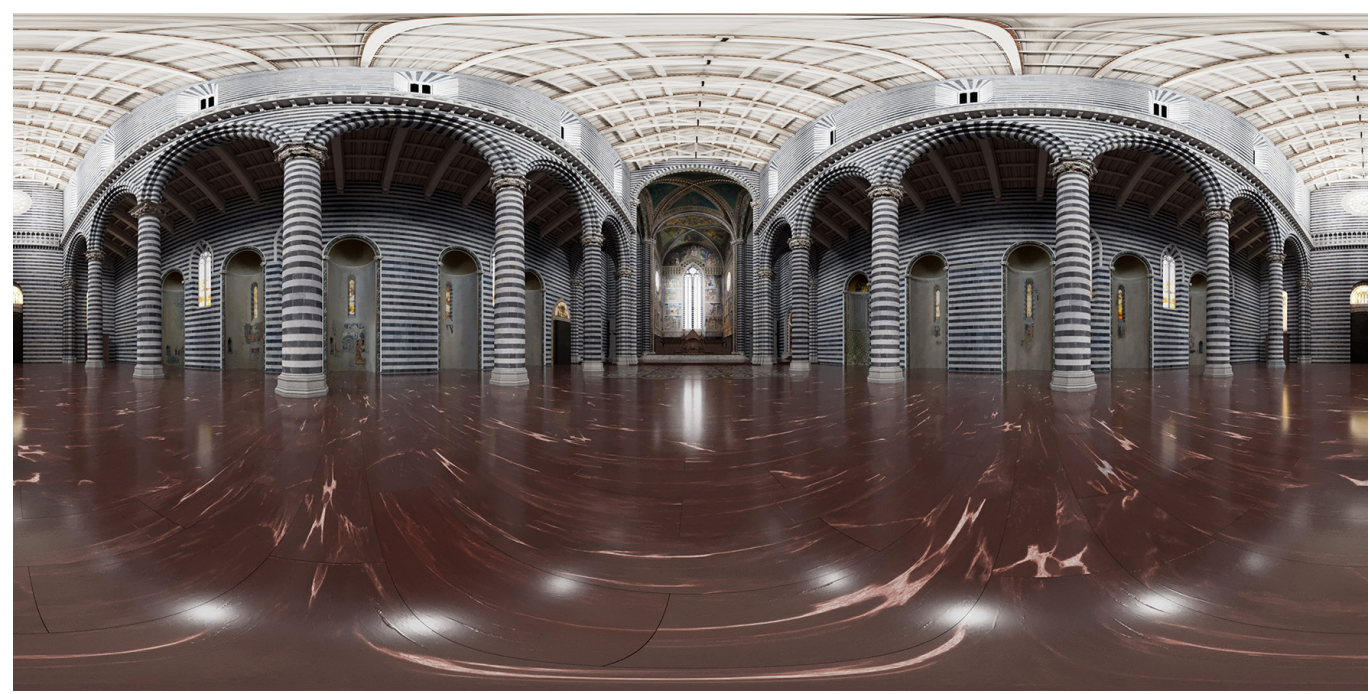

Fig. 10. Ricostruzione panoramica in formato equirettangolare dell'interno del Duomo nell sua fase cinquecentesca.

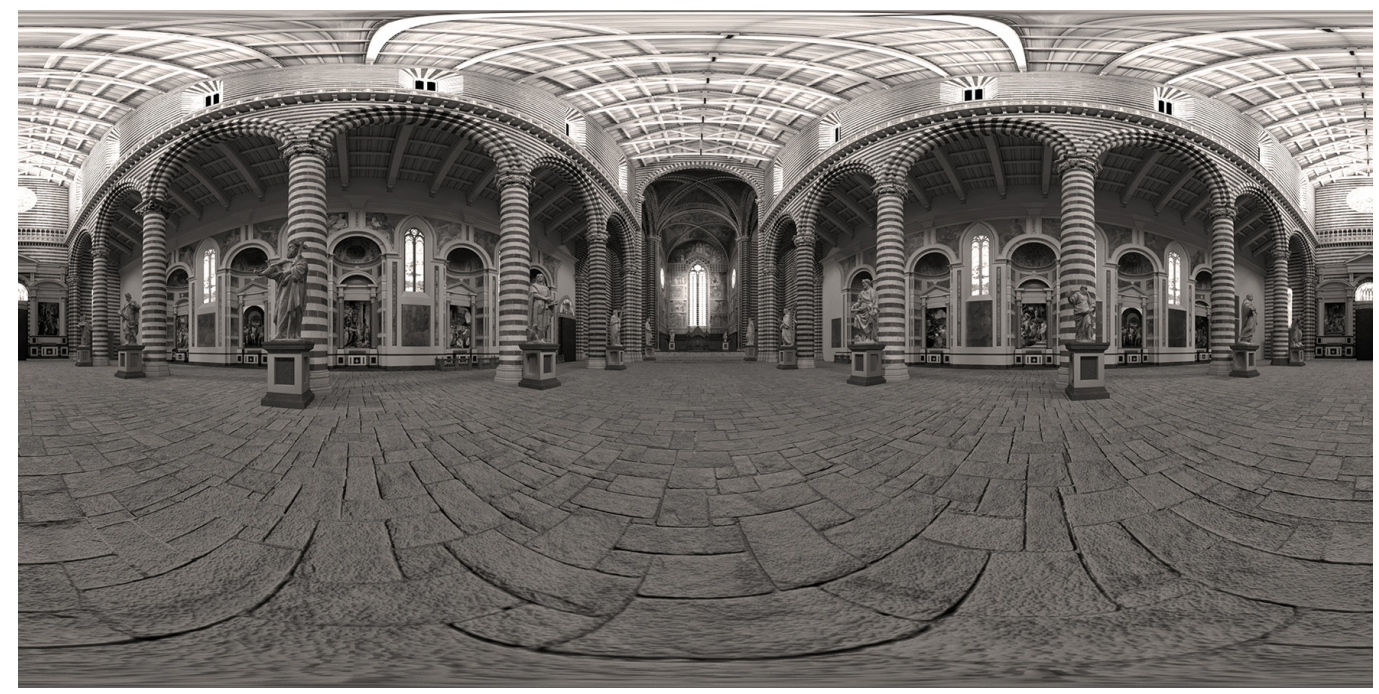


Nebbia e Ferrante Fancelli, alcuni degli artisti che hanno lavorato allinterno del Duomo durante le modifiche cinquecentesche.

Già artisti come Raffaello, Peruzzi e Palladio hanno affrontato un tipo di restauro per così dire grafico, per restituire alla contemporaneità le grandezze di Roma, ormai ridotte a ruderi. Anche Vitet, uno dei maestri di Viollet Le Duc, di fronte alle rovine del castello di Coucy, teorizza un restauro per il quale non si avrà bisogno di pietre o cemento, ma solo di pochi fogli di carta [9].

E oggi, mutatis mutandis, quei fogli di carta sono rappresentati dalle nuove tecnologie, che possono costituire - se usate correttamente [ 10$]$ - un utilissimo strumento di supporto alla conoscenza del costruito storico.

All'evoluzione della metodologia della ricerca corrisponde anche una discussione sulla comunicazione e sull'educazione, legate strettamente alle caratteristiche di una percezione mutevole del valore didattico. Fino a pochi anni fa, infatti, la visione storica era prevalentemente limitata ai ricercatori e agli esperti del settore, ai possessori, cioè, dei codici di interpretazione dell'architettura antica.

Grazie alle nuove tecnologie, invece, si moltiplicano le possibilità di immersione nell'ambiente virtuale, facilitando l'approccio esperienziale al costruito storico da parte di qualunque fruitore.

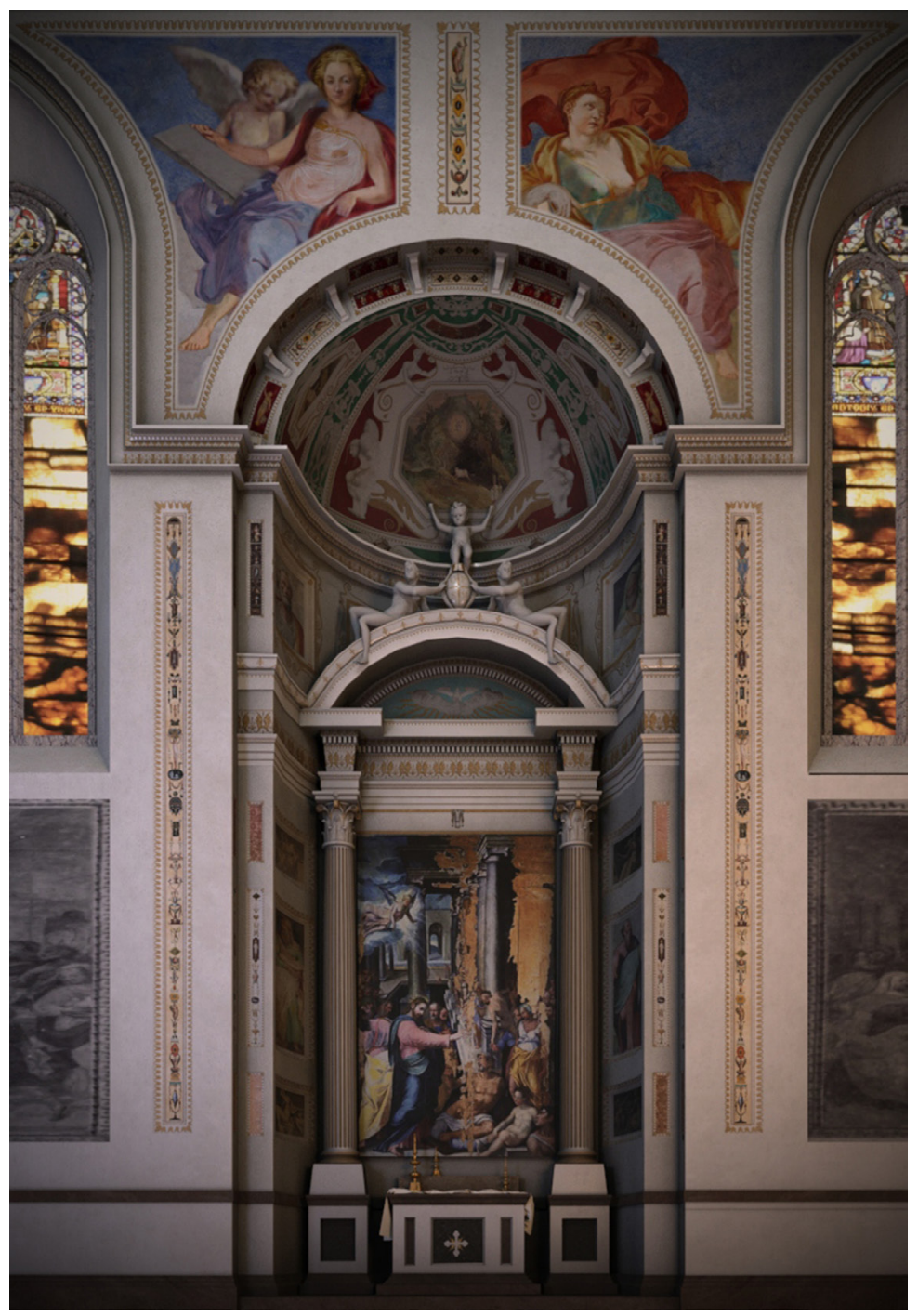




\section{Note}

[I] Per una trattazione esaustiva circa le vicende costruttive della cattedrale si vedano i volumi: Bonelli 1943; Bonelli 1972; Fumi 1891; Franchetti Pardo 2014; Riccetti 1988.

[2] https://www.agisoft.com

[3] Per un primo approccio alle problematiche legate a questo e ad altri tipi di rilievo si vedano: Chiavoni, Paolini 2007; De Luca 201 I; Docci 2005; Remondino, El-Hakim 2006.

[4] Si veda: Bianchini, Borgogni, Ippolito, Senatore, Capiato, Capocefalo, Cosentino 20 I2; D'amelio, Lo Brutto 2009; Guarnieri, Remondino, Vettore 2004.

[5] Si veda, relativamente all'utilizzo di modelli discreti e continui nella rappresentazione dell'architettura, Bianchini 200 I.

[6] Per un maggior approfondimento su tale ciclo decorativo si veda: Cambareri 1998; Cambareri, Roca De Amicis 2002; Onori 201 I; Satolli 1978; Tosini 2010.

[7] II restauro è ampiamente documentato da Fumi I89|; Muratore, Loiali 2005; Zampi | 889.

[8] Tale ricostruzione è stata possibile grazie al supporto fondamentale della storica dell'arte Elena Bastianini e del 3d artist Andrea Cigognetti, che hanno permesso di restituire un'immagine plausibile della cappella.

[9] Vitet Louis, Rapport présenté au Ministre de I'Intérieur sur la conservation del Monuments Historiques de France, I 83 I.

[10] Per le problematiche legate all'utilizzo delle nuove strumentazioni, si veda la Carta di Londra del 2009 (http://www. londoncharter.org/). II documento, riconoscendo l'importanza dei modelli tridimensionali nel campo dei beni culturali, nasce con l'obiettivo di definire princìpi relativi all'uso dei metodi di visualizzazione tridimensionale in relazione all'integrità intellettuale, all'affidabilità, alla trasparenza, alla documentazione, e alle possibilità di accesso ai dati.

\section{Riferimenti bibliografici}

Bianchini Carlo (200I). Modelli discreti e modelli continui nel rilievo e rappresentazione informatizzata dell'architettura. In Disegnare. Idee, immagini, 22, 200 I, pp. 5 I-60.

Bianchini Carlo, Borgogni Francesco, Ippolito Alfonso, Senatore Luca James, et al. (2012). Laser scanner surveys vs low-cost surveys. A methodological comparison. In Di Giamberardino Paolo, lacoviello Daniela, Natal Jorge Renato, Tavares João Manuel (eds.). CompIMAGE 20 I 2, Computational Modeling of Objects Presented in Images: Fundamentals, Methods and Applications - 3rd Edition. Atti del Convegno Internazionale. Roma, 5-7 Settembre 20 I 2. London: CRC Press, pp. 453-457.

Bonelli Renato (1943). Fasi costruttive e organismo architettonico nel Duomo di Orvieto. Bagnoregio: Marsili.

Bonelli Renato (1972). II Duomo di Orvieto e l'architettura italiana del Duecento Trecento. Roma: Officina.

Cambareri Marietta (1998). Ippolito Scalza and the Sixteenth-Century Renovation Projects at Orvieto Cathedral. PhD dissertation, New York: Institute of Fine Arts, New York University.

Cambareri Marietta, Roca De Amicis Augusto (2002). Ippolito Scalza. Perugia: Quattroemme.

Chiavoni Emanuela, Paolini Priscilla (a cura di). (2007). Metodi e tecniche integrate di rilevamento per la realizzazione di modelli virtuali dell'architettura e della città. Roma: Gangemi.

D'Amelio Salvatore, Lo Brutto Mauro (2009). Analisi e comparazioni di modelli di superficie di reperti archeologici realizzati tramite laser scanner e fotogrammetria. In Atti della XIII Conferenza Nazionale ASITA, Bari I -4 Dicembre 2009, pp. 84 I-846.

De Luca Livio (20l I). La fotomodellazione architettonica. Rilievo, modellazione, rappresentazione di edifici a partire da fotografie. Palermo: Dario Flaccovio.

Docci Mario (2005). Metodologie innovative integrate per il rilevamento dell'architettura e dell'ambiente. Roma: Gangemi. Fumi Luigi (|89|). II Duomo di Orvieto e i suoi restauri; monografie storiche condotte sopra i documenti. Roma: Società Laziale tipografica.

Franchetti Pardo Vittorio (20 I4). La cattedrale di Orvieto: origine e divenire. Scritti editi e inediti. Perugia: Deputazione di Storia Patria per l'Umbria.

Guarnieri Alberto, Remondino Fabio,Vettore Antonio (2004). Photogrammetry and Ground - based laser scanner:Assessment of metric accuracy of the 3D model of Pozzoveggiani Church. In FIG Working Week 2004. TS on Positioning and measurement Technologies and Pratices II - Laser Scanner and Photogrammetry, Atene: <https://fig.net/resources/proceedings/fig_proceedings/ athens/papers/ts26/TS26_4_Guarnieri_et_al.pdf>.

Muratore Giorgio, Loiali Patrizia (2005). Paolo Zampi ( $1842-19$ | 4). Orvieto: Fondazione Cassa di Risparmio di Orvieto.

Onori Elena (20 I I). Un secolo nemico a le Lettere e a l'Arti ti tolse lo splendore de 'I tuo bel manto antico. II Duomo di Orvieto: fucina delle arti dopo il Concilio di Trento. In Bollettino Istituto Storico Artistico Orvietano, LXVII, pp. 2 I 5-236.

Remondino Fabio, El-Hakim Sabry (2006). Image-based 3D modeling: a review. In The Photogrammetric Record Journal, 2 I, I I 5 , pp. 269-291.

Riccetti Lucio (a cura di). (1988). II Duomo di Orvieto. Roma-Bari: Laterza. 
Satolli Alberto (1978). Documentazione inedita sugli interventi cinquecenteschi nel duomo scomparsi con i restauri del 1877 , in appendice a ID., Quel bene detto duomo. In Bollettino Istituto Storico Artistico Orvietano, XXXIV, pp. I29- 160.

Tosini Patrizia (20 I0). II Duomo di Orvieto nella seconda metà del Cinquecento: un modello per la pittura della Controriforma. In Benocci Carla, Della Fina Giuseppe, Fratini Corrado (a cura di). Storia di Orvieto. Pisa: Pacini.

Zampi Paolo ( 1889 ). Notizie sui lavori di restauro eseguiti per la copertura del Duomo di Orvieto. In L'Ingegneria civile e le arti industriali, XV, pp. 5-29.

Autori

Roberto Barni, Sapienza Università di Roma, roberto.barni@hotmail.it

Carlo Bianchini, Sapienza Università di Roma, carlo.bianchini@uniromal.it

Carlo Inglese, Sapienza Università di Roma, carlo.inglese@uniromal.it

Per citare questo capitolo: Barni Roberto, Bianchini Carlo, Inglese Carlo (2020). Il duomo di Orvieto. Rilievo integrato e modellazione/The Cathedral of Orvieto. Integrated Survey and Modeling. In Arena A., Arena M., Brandolino R. G., Colistra D., Ginex G., Mediati D., Nucifora S., Raffa P. (a cura di). Connettere. Un disegno per annodare e tessere. Atti del $42^{\circ}$ Convegno Internazionale dei Docenti delle Discipline della Rappresentazione Connecting. Drawing for weaving relationships. Proceedings of the 42th International Conference of Representation Disciplines Teachers. Milano: FrancoAngeli, pp. 1678-1699. 


\title{
The Cathedral of Orvieto. Integrated Survey and Modeling
}

\author{
Roberto Barni \\ Carlo Bianchini \\ Carlo Inglese
}

\section{Abstract}

The article presents the results of a study conducted on the Orvieto cathedral through the creation of models created from structure from motion processes, using parametric polygonal models. The results presented, analyzing the different modeling methodologies used, come to a diachronic reconstruction of the duomo, with particular attention to the material and decorative elements of one of the side chapels.

Keywords

survey trough SFM, Orvieto Cathedral, parametric polygonal modeling, Virtual Reality.

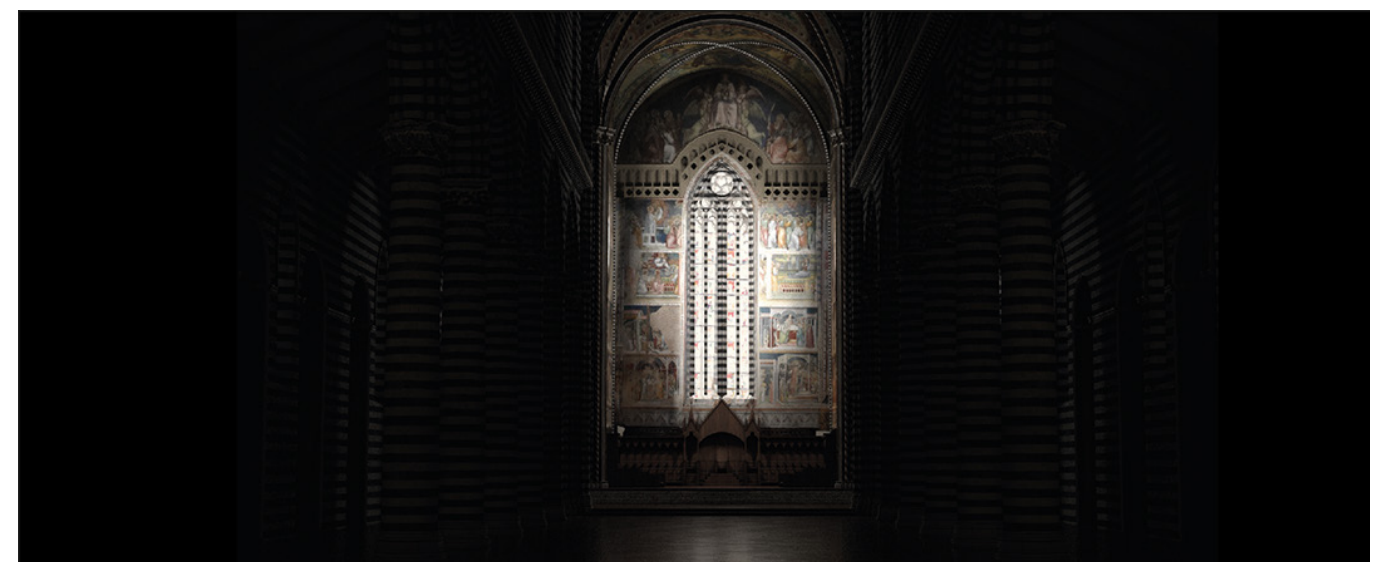




\section{Introduction}

Symbol of Orvieto, the Duomo is one of the main and most important cathedrals of Italian Gothic. The beginning of the construction works dates to 1290, when Pope Nicholas IV laid the foundation stone [I].

The original scheme of the cathedral had a basilica shape with three naves and a transept. The plan had six semi-circular chapels on each side and an apse grafted on the transept, also semi-circular (fig. Ia).

Starting from I 308 Lorenzo Maitani is documented in the construction site with the position of universalis capud magister. He is credited with the design of the so-called tricuspidal facade, as well as the construction of three pairs of rampant spurs parallel to the walls of the tribune and of the two large chapels (fig. Ib).

Taking advantage of the layers of these consolidation works, in the following years, environments will be created that will distort the original spatiality of the cathedral, defining its current appearance: the new tribune (I328- | 335), the Corporal Chapel (I 350- I 356) and the Nova Chapel ( 1406 - I444) also called Madonna of San Brizio's Chapel (fig. Ic).

\section{Methodological approach}

The knowledge of a monument in its spatial configuration and in its relationship between the parts is the most important purpose of the survey operations: it is made possible through the critical reading of the data and the integration of the information, systematized according to criteria shared by the operators of the survey sector and those of other sectors. The construction of a digital copy of the investigated object allows you to retrace the same research process that, starting from the excavation phase and, proceeding to subsequent stratigraphic levels, arrives at the interpretation of the context and its transformations.

In the digital model, this investigation process loses its temporal and spatial limit: in fact, the model can always be inspected and, above all, always in a reversible way; Furthermore, the same model can be discretized by considering only portions and levels individually, corresponding to historical phases or stratigraphies useful for understanding the data. This peculiarity of the digital model allows the monument to be visualized according to parameters and investigation paths that are more effective than those that can be tested on site.

The possibilities of the digital instrument are important to achieve the aim of knowledge: as part of the investigations carried out in the cathedral of Orvieto, it was necessary to acquire various types of data in a very limited period of time, compatible with the needs of site protection and security. The structure of the investigation context suggested the

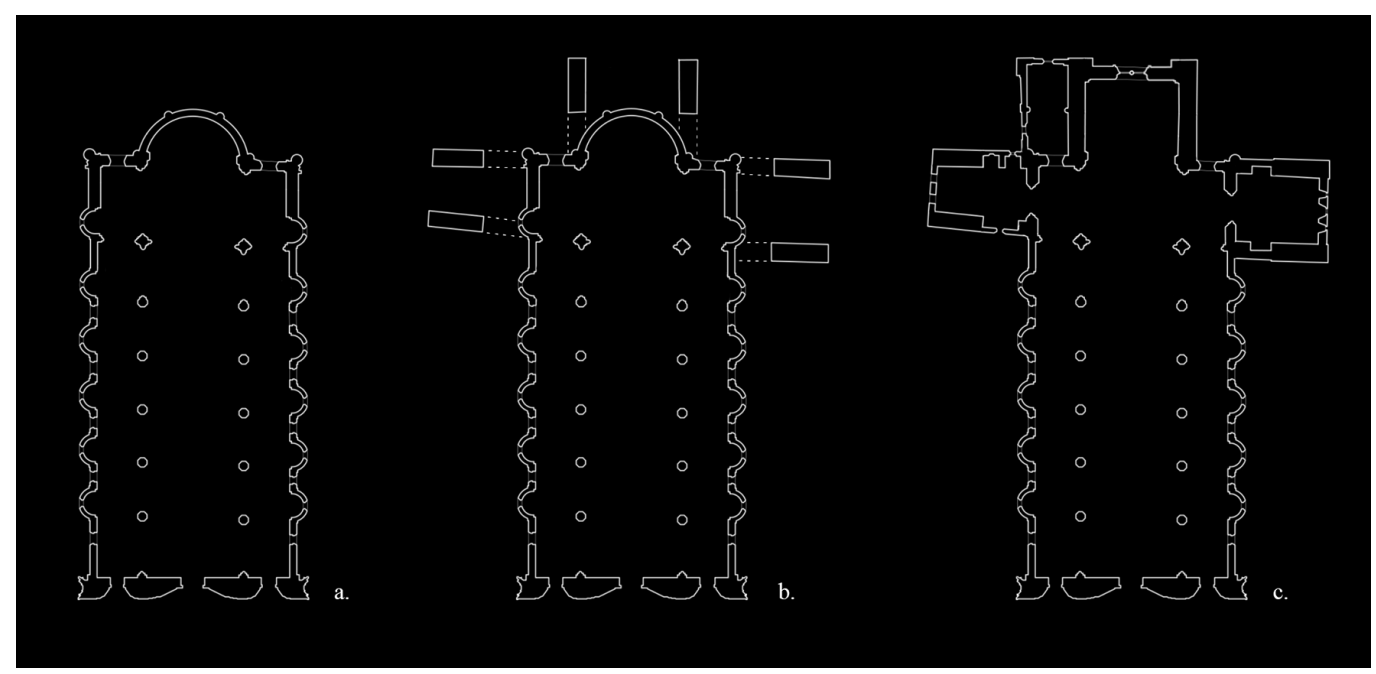


relevant methodology to follow: the limited accessibility, from a temporal point of view, and the particular spatial configuration of the cathedral made the implementation of acquisition systems for SfM (SFM - Structure from Motion) that would allow the area to be covered in its entirety and that would produce an easy to read and metric reliable virtual model.

\section{Architectural survey project and data processing}

This context has placed the emphasis on the use of the SfM process, not only for its cheapness and portability, but also to solve the problem related to the static nature of the acquisition set imposed by the laser scanner: the camera, used as data acquisition tool, select a remarkable versatility in the organization of the survey campaign and organized the subdivision of the entire monument into different photographic sets.

The data processing was carried out using the Agisoft Metashape software [2]. Based on the latest 3D multi-view reconstruction technology, this program allows you to acquire metric data of an object through the analysis of frames, which must have a certain percentage of overlapping (generally not less than 60\%).

The procedure for generating the 3D model, starting from the acquisition of the photographic material, consists of four main phases.

The first phase consists of importing the acquired photos into the program and their subsequent alignment: Metashape analyses the common points between the photos, determines the position of the camera for each image and returns the alignment. As a result, it generates a first scattered cloud of points of the entire photographed setting (fig. 2a).

To optimize the work, the scene is limited with a bounding box that delimits the processing of the object of interest, making it possible to create a cloud full of points, obtained by calculating the measurements detected from the surface of the photographed object. Already in this phase the object of study is perceived in its entirety, which is not yet a workable element as regards polygonal modeling (fig. 2b).

The third phase is the construction of the mesh of the model, i.e. the network of polygons that make up the geometry of the solid, reconstruction based on the arbitrary algorithm, applicable to any type of object (fig. 2c). After generating the mesh, corrections can be performed on the latter, such as its decimation, the removal of detached components, the closure of holes, etc. directly within the program.

To make the final appearance of the object it is necessary to generate the texture: a two-dimensional image in raster format that is reproduced on the faces of the three-dimensional polygonal model (fig. 2d). The reconstructed geometry, therefore, can be used for the generation of orthophotos.

The process was explained through the statue of San Rocco (fig. 2), made in 1593 by the sculptor Fabiano Toti for the counter-facade of the cathedral of Orvieto. The previously described data acquisition methodology can be applied both to small-sized objects - such

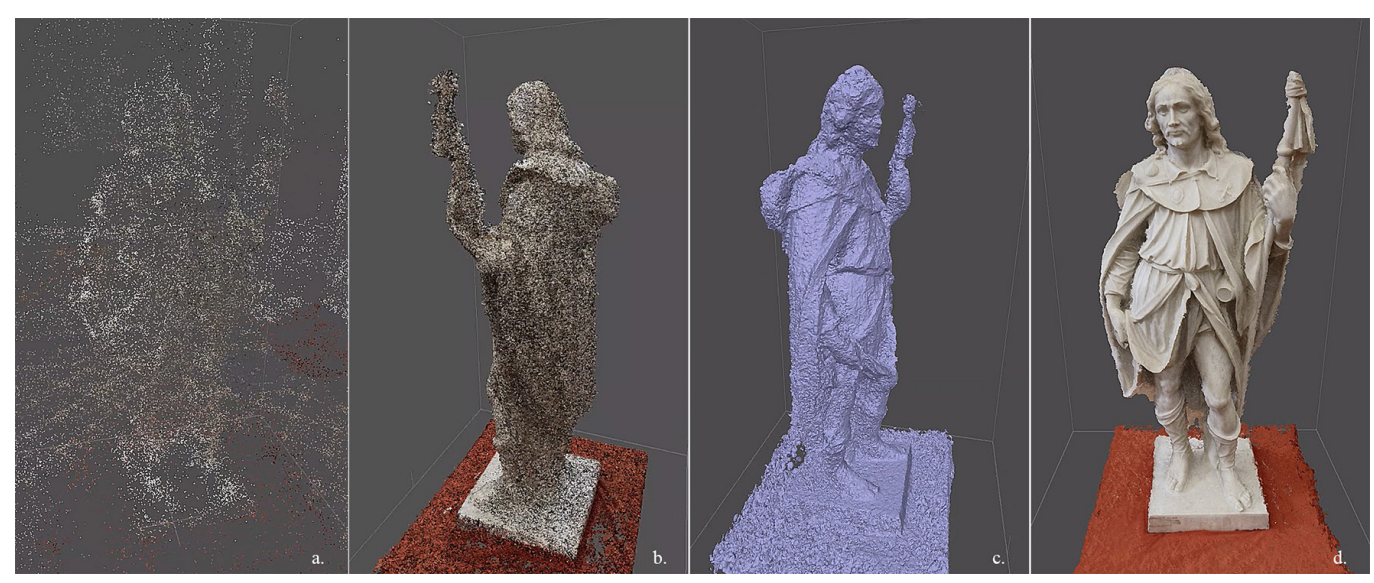


as the aforementioned statue, just $1.90 \mathrm{~m}$ high - as well as to complex buildings of considerable size, such as the entire cathedral (fig. 3).

This technique has some limitations related to the lack of data (elements that cannot be photographed), as well as errors due to the data acquisition procedure (operator and medium used) or to the processing of the same data (inaccuracies of the model) [3]. Thanks to previous studies [4], it can be assumed that - for buildings of the order of size of the entire cathedral - the error may be $8-10 \mathrm{~cm}$. Obviously, this error can be acceptable for the purposes of this study: the enhancement of the site; but it would not be acceptable for structural monitoring.

\section{Modeling}

The numerical model developed by the program has an infinite number of polygons which make it less workable from the point of view of modeling (fig. 4). Therefore, it is necessary to simplify it, creating a mathematical model, also called Low Poly, consisting of a few polygons (fig. 5).

A polygonal modeling was used for the cathedral of Orvieto, which differs from the Nurbs model by the algorithm underlying the model creation process.

The Nurbs (Non-Uniform Rational Be Spline) modeling is based on the creation of Bezier and spline curves, which allow perfect control of the surfaces that are generated. On the other side, the polygonal modeling is based on the approximation - more or less likely - of the real objects, while allowing a more flexible management of the geometry of the model. For example, in a software like Rhinoceros, which is based on Nurbs modeling, a square is the result of the four curves that delimit it and only these curves will be editable. While in polygonal modeling software, such as Cinema 4D or Modo, a square is the result of the combination of vertices, edges and faces: all these elements will be editable.

A polygonal parametric modeling program such as Modo (used together with Cinema 4D to model the cathedral of Orvieto) allows you to start from primary solids, such as the cube, cylinder or sphere, and then modify them, selecting the vertices, the edges or the faces, up to create complex shapes [5].

The processes involving the creation of a 3D image do not end with the modeling of the object, but involve other essential steps, such as UV mapping, texturing, lighting, and rendering.

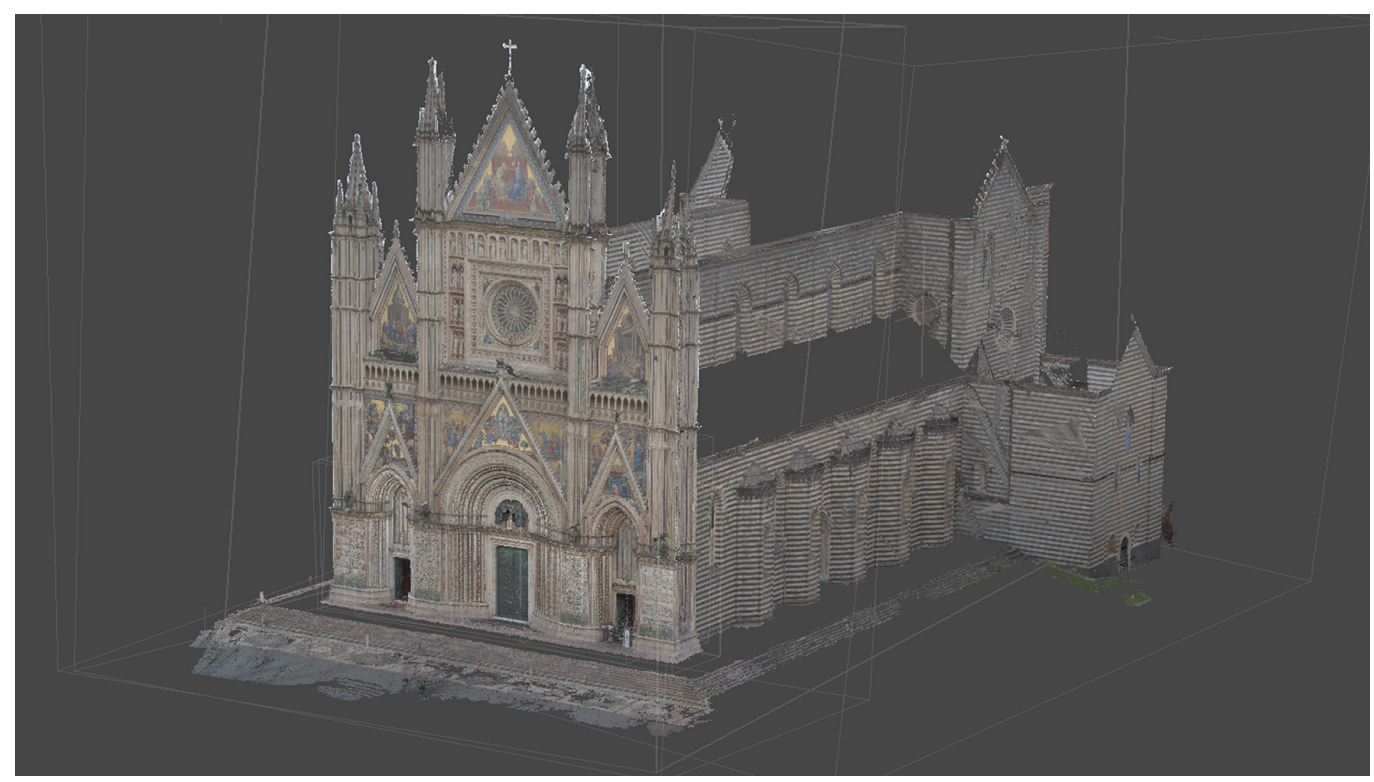




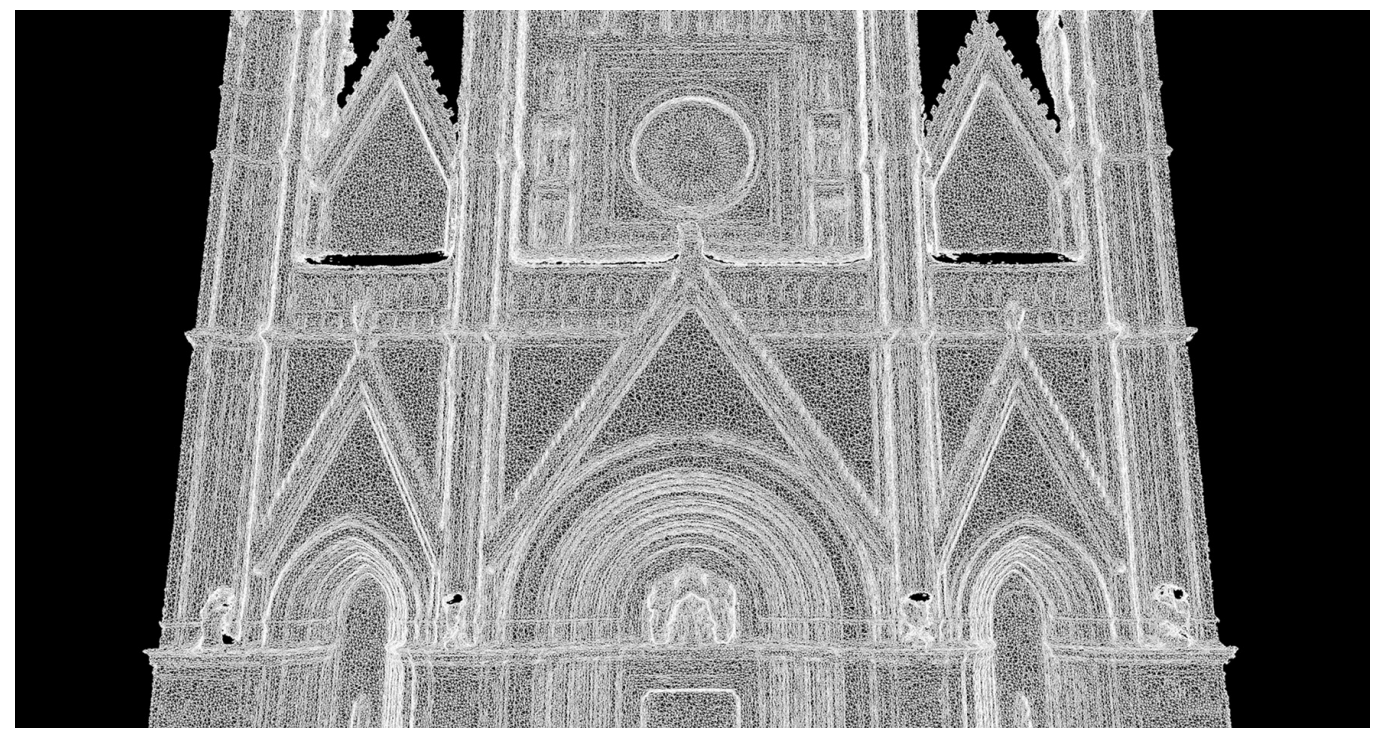

A fundamental step is the mapping, or UV mapping: complex geometries, such as the twisted columns on the facade, must be developed on a plane through unwrapping. At this point, each vertex of the three-dimensional object will have a set of two-dimensional coordinates shared with the image, which can be associated with its faces, resulting visible in 3D space. To check the quality of the UV mapping created, it is good practice to use a check texture called checker, which allows you to check - through a raster image formed by a square grid of numbers and colours - if the Unwrapping projection is correct (fig. 6a).

Once the unwrapping is complete, you can proceed with the texturing, which allows you to project one or more textures - previously made with photo editing programs, such as Adobe Photoshop - on the surface of a 3D model, using the UV coordinates (fig. 6b). It makes the model more detailed and realistic.

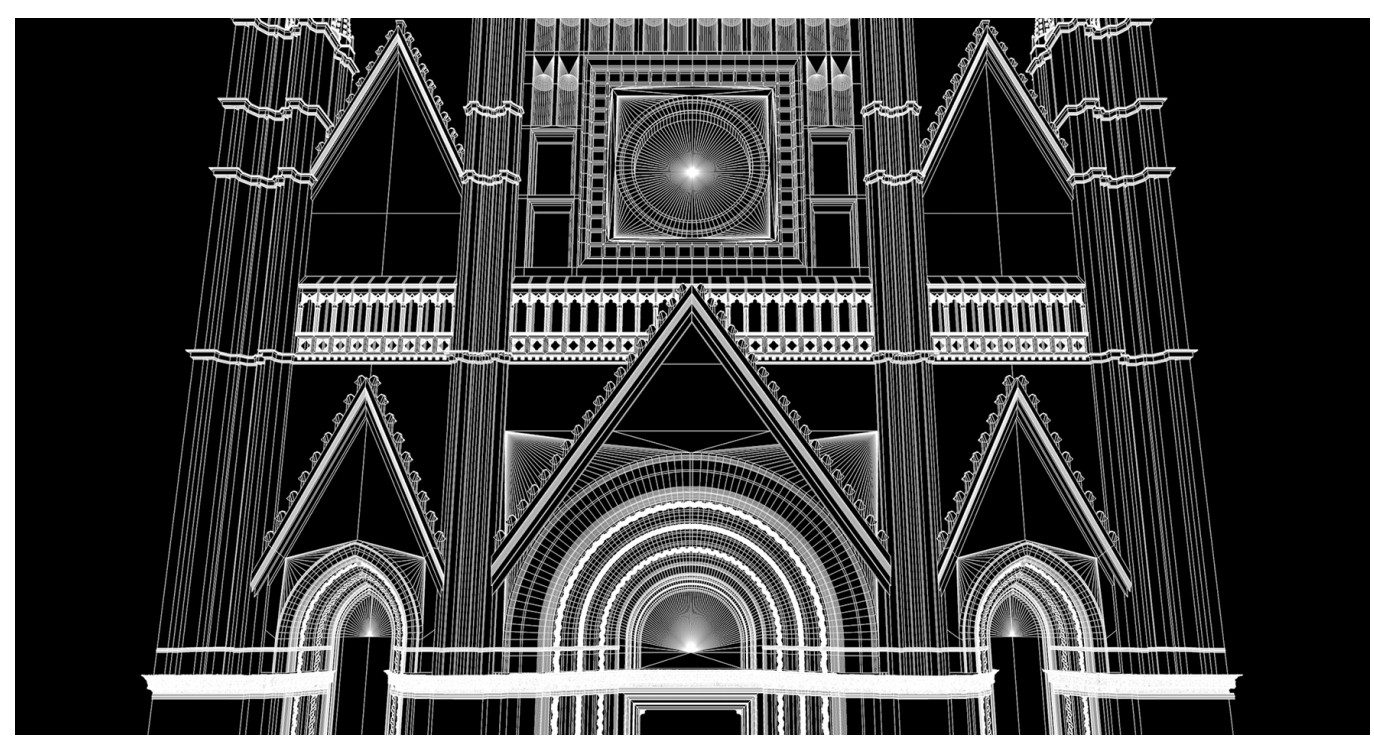


To finish the workflow, the last step is rendering (in this case made with the Corona Renderer engine for Cinema 4D), a process through which a 2D image is generated from the 3D scene. The balance of lights, the rendering of the materials and the photographic cut of the scene greatly affect the success of a realistic render (figs. 7, 8).

To pursue the intent of enhancement, we have used devices that allow total immersion within the scene, through panoramic renders in equirectangular format, visible at $360^{\circ}$ thanks to VR viewers (fig. 9).

\section{Conclusions: knowledge, enhancement, publication}

The restitution of the image also aims at the knowledge of the sixteenth-century construction phase, now lost and shown here in black and white (fig. I0).

In fact, between 1556 and I575, ten chapels were built in the lateral aedicules and two inside the counter-façade, each consisting of an altar, surmounted by a large altarpiece framed by stuccos, marbles, grotesques and frescoes [6]. This decorative cycle, strongly anchored to the counter-reform principles dictated by the Council of Trent, has been lost. Between I 877 and I89I, in fact, Eng. Zampi, with the support of the historian Luigi Fumi, carries out a restoration of the medieval facies of the monument [7].

The project we have tried to pursue aims to offer a reading of the space of the sixteenth-century phase, now lost, unrepeatable from a material point of view. The chromatic reconstruction was attempted only for the third chapel on the left (fig. II) [8]. This result was possible thanks to a philological comparison between the historical photos, taken before the restoration, and the works made in those years by the painters and decorators who worked inside the cathedral.

The most similar cycle is found in the palace of cardinal Girolamo Simoncelli, in Torre San Severo, near Orvieto. We can still see the decorations of three rooms of this building, with sacred and profane themes, framed by grotesques, works by Girolamo Muziano, Cesare Nebbia and Ferrante Fancelli, some of the artists who worked inside the Cathedral during the sixteenth century modifications.

Artists such as Raffaello, Peruzzi and Palladio have faced a type of graphic restoration, to return the greatness of Rome, now reduced to ruins. Even Vitet, one of the masters of Viollet Le Duc, facing the ruins of the castle of Coucy, theorizes a restoration in which you will not need stones or concrete, but only a few paper sheets [9].

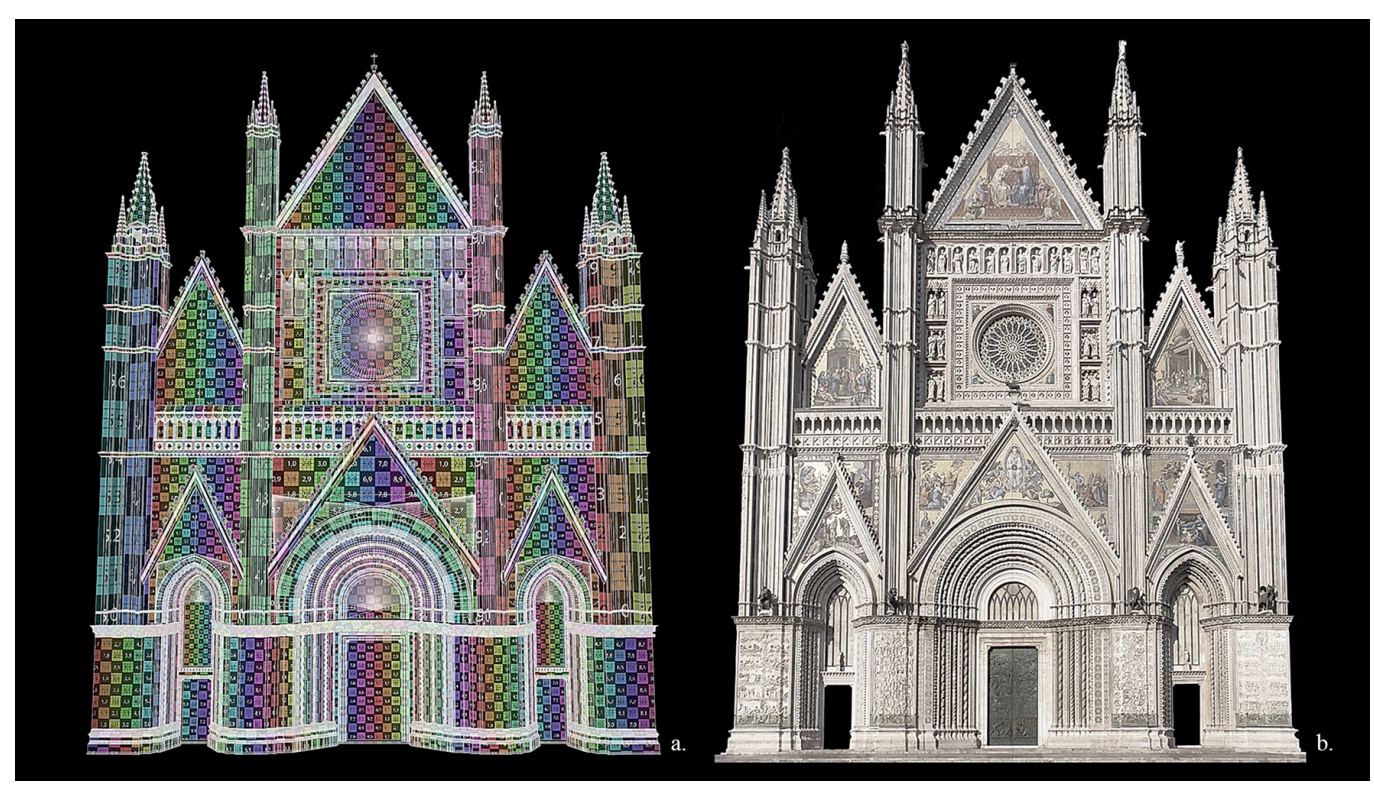




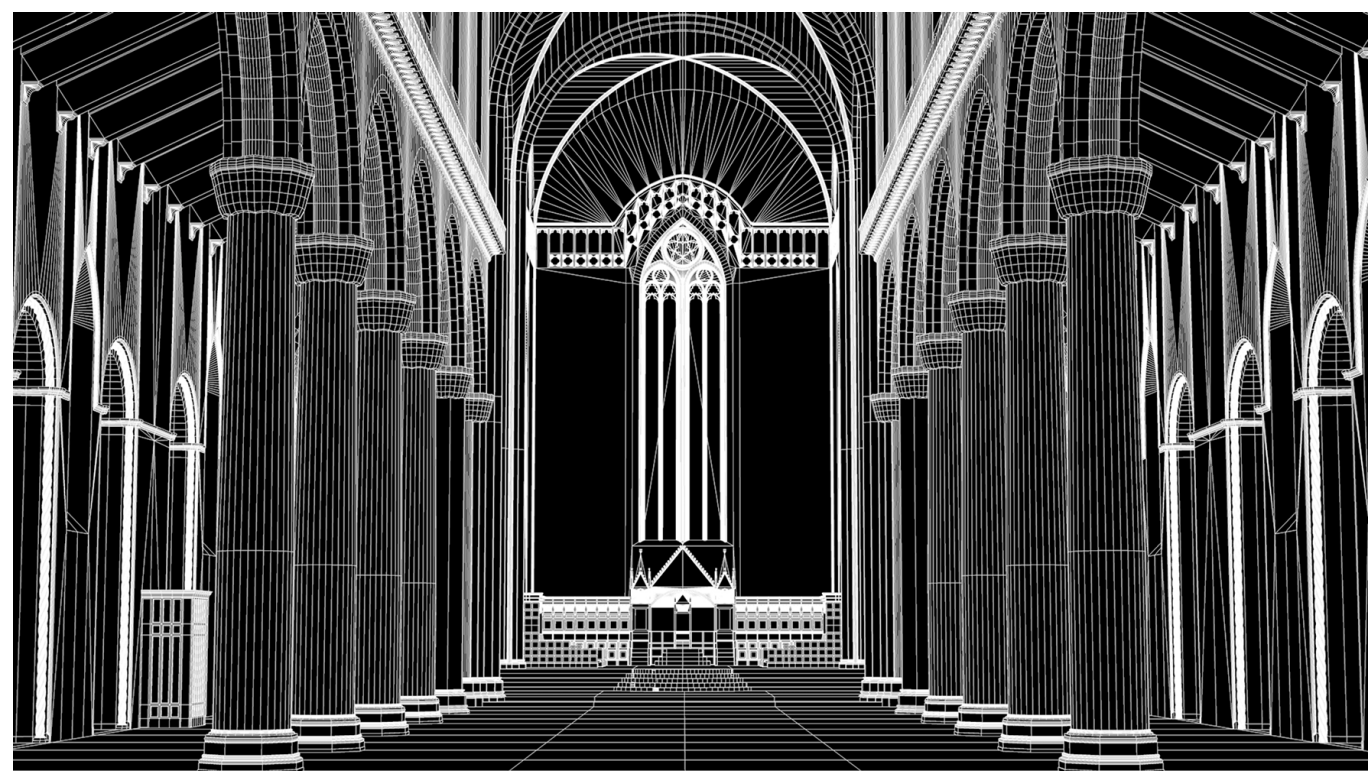

Fig. 8. Rendered view of the interior of the Duomo.

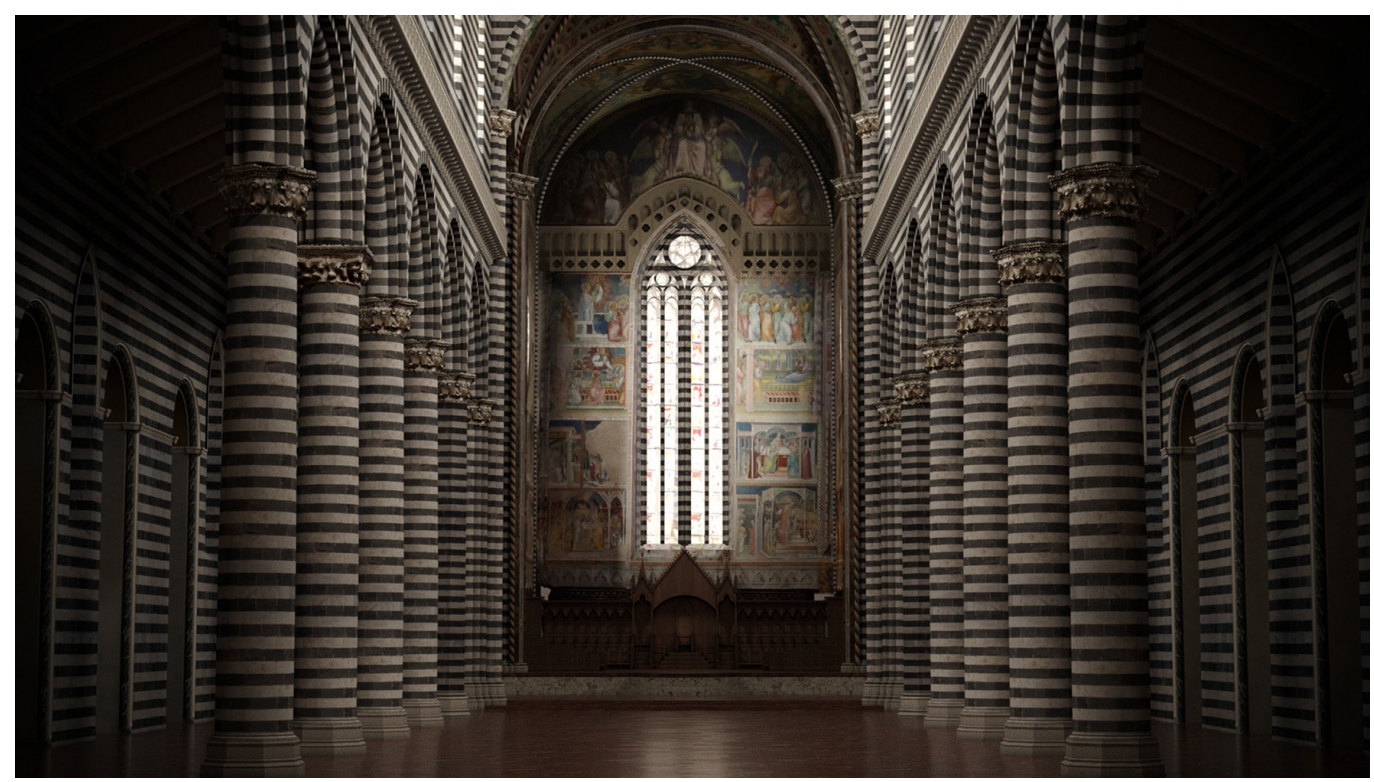


Fig. 9. Panoramic view

rendered in equirectan-

gular format of the

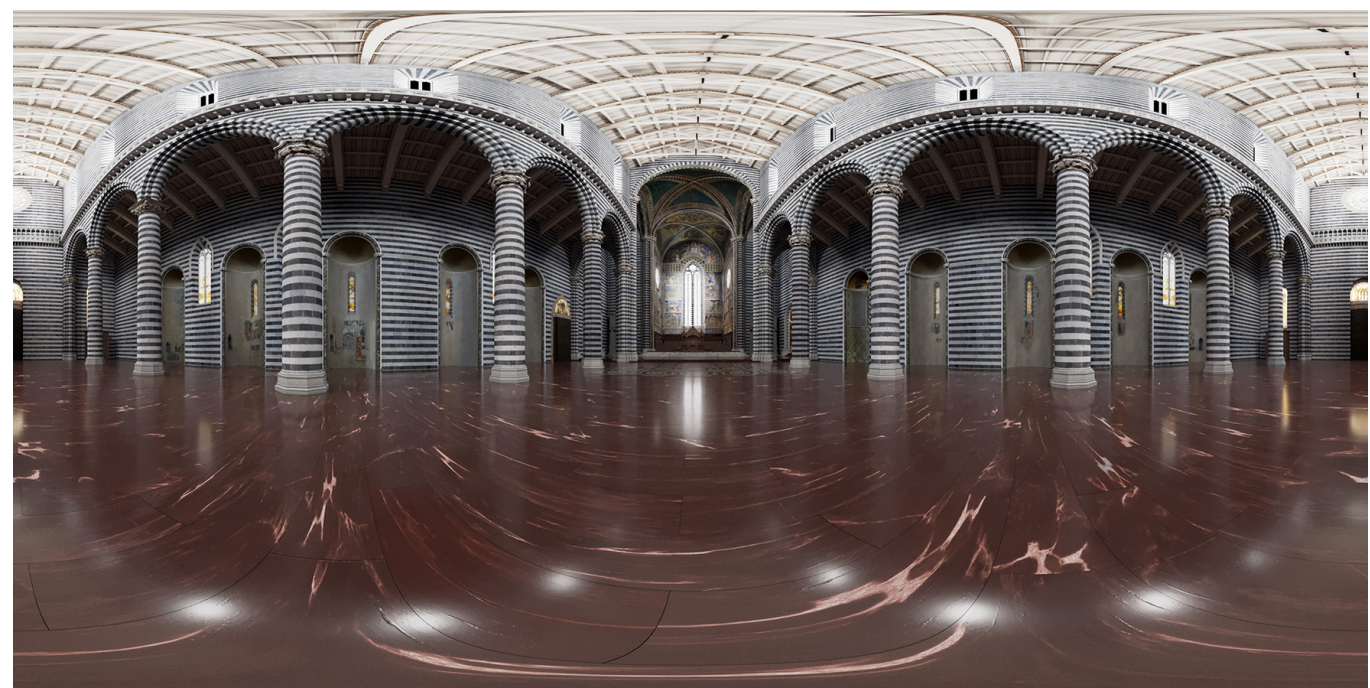

Fig. 10. Panoramic recon-

struction in equirectangu-

ar format of the interio

of the Cathedral during

its sixteenth-century

phase.

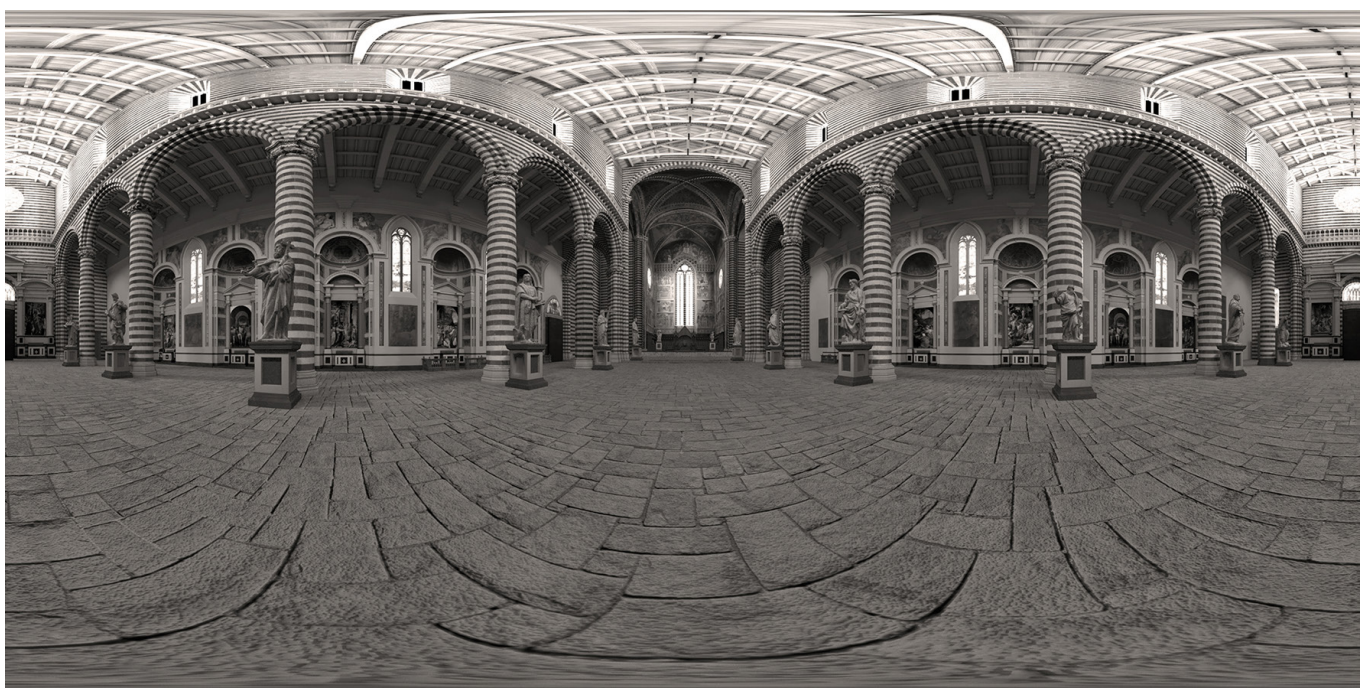


And today, mutatis mutandis, those sheets of paper are represented by new technologies, which can constitute - if used correctly [I0] - a very useful tool to support historical building knowledge.

The evolution of the research methodology is accompanied by a discussion on communication and education, closely linked to the characteristics of a changing perception of the didactic value. Until a few years ago, in fact, the historical vision was mainly limited to researchers and experts in the sector, to the owners of the codes of interpretation of ancient architecture.

Thanks to new technologies, however, the possibilities of immersion in the virtual environment multiply, facilitating the experiential approach to the historical building by any user.

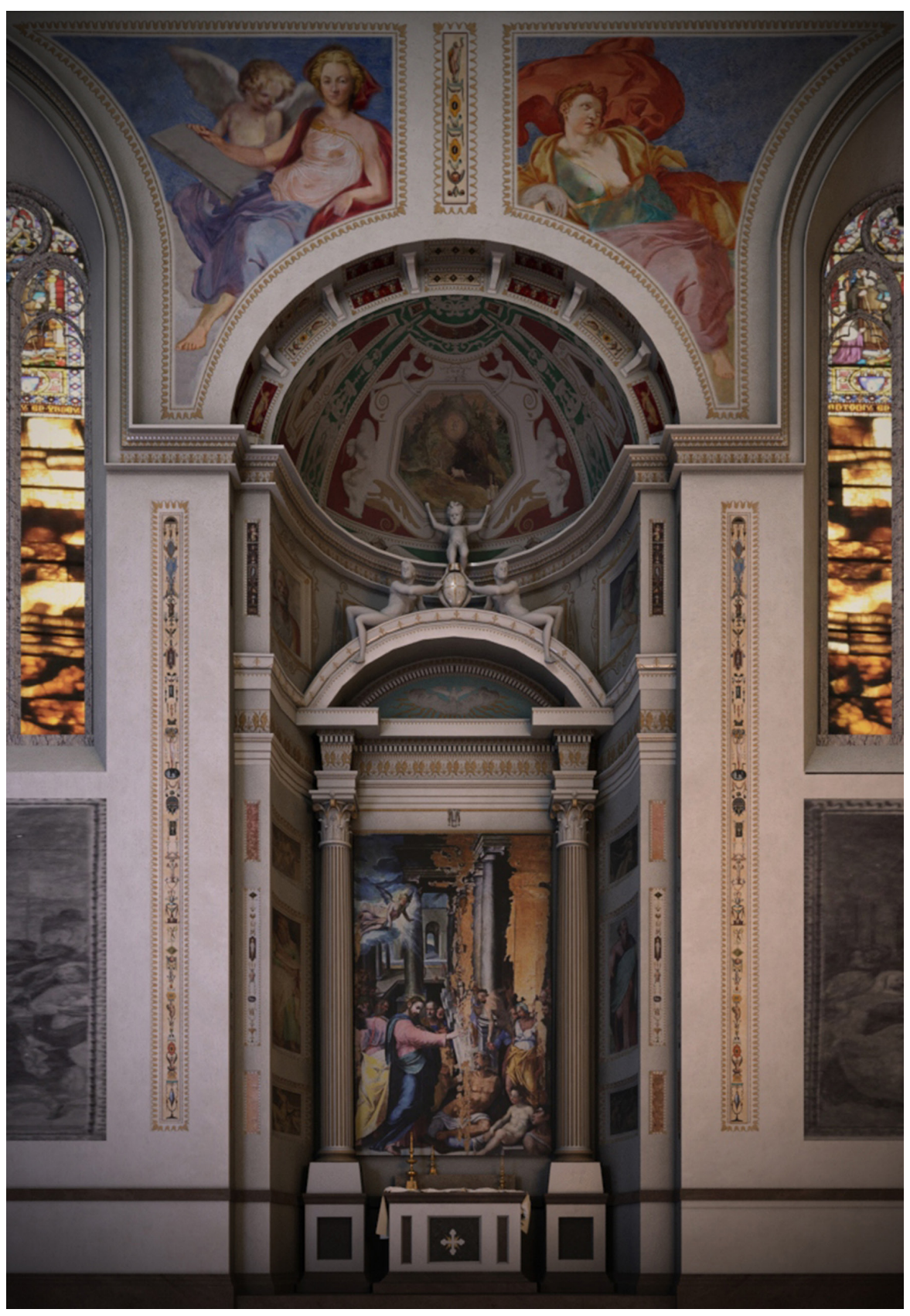




\section{Notes}

[I] For an exhaustive discussion about the construction of the cathedral, see the volumes: Bonelli 1943; Bonelli I972; Fumi 1891; Franchetti Pardo 2014; Riccetti 1988

[2]See: <https://www.agisoft.com>.

[3] For a first approach to the problems related to this and other types of relief see: Chiavoni, Paolini 2007; De Luca 20 I I; Docci 2005; Remondino, El-Hakim 2006

[4] Bianchini, Borgogni, Ippolito, Senatore, Capiato, Capocefalo, Cosentino 2012; D'Amelio, Lo Brutto 2009; Guarnieri, Remondino, Vettore 2004.

[5] See, regarding the use of discrete and continuous models in the architecture representation, Bianchini 200।

[6] For further information on this decorative cycle, see: Cambareri 1998; Cambareri, Roca De Amicis 2002; Onori 2011; Satolli 1978; Tosini 2010.

[7]The restoration is widely documented by Fumi I891; Muratore, Loiali 2005; Zampi 1889.

[8] This reconstruction was possible thanks to the fundamental support of the art historian Elena Bastianini and the 3d Artist Andrea Cigognetti, who allowed us to return a plausible image of the chapel.

[9]Vitet Louis, Rapport présenté au Ministre de l'Intérieur sur la conservation del Monuments Historiques de France, I83 |.

[10] For issues related to the use of new equipment, see the London Charter of 2009 (http://www.londoncharter.org/). The document, recognizing the importance of three-dimensional models in the field of cultural heritage, was born with the aim of defining principles relating to the use of three-dimensional visualization methods in relation to intellectual integrity, reliability, transparency, documentation, and the possibilities of accessing data.

\section{References}

Bianchini Carlo (200 I). Modelli discreti e modelli continui nel rilievo e rappresentazione informatizzata dell'architettura. In Disegnare. Idee, immagini, 22, 200 I, pp. 5 I-60.

Bianchini Carlo, Borgogni Francesco, Ippolito Alfonso, Senatore Luca James, et al. (2012). Laser scanner surveys vs low-cost surveys. A methodological comparison. In Di Giamberardino Paolo, lacoviello Daniela, Natal Jorge Renato, Tavares João Manuel (eds.). ComplMAGE 20 12, Computational Modeling of Objects Presented in Images: Fundamentals, Methods and Applications - 3rd Edition. Atti del Convegno Internazionale. Roma, 5-7 Settembre 20 I 2. London: CRC Press, pp. 453-457.

Bonelli Renato (1943). Fasi costruttive e organismo architettonico nel Duomo di Orvieto. Bagnoregio: Marsili.

Bonelli Renato ( 1972). II Duomo di Orvieto e l'architettura italiana del Duecento Trecento. Roma: Officina.

Cambareri Marietta (1998). Ippolito Scalza and the Sixteenth-Century Renovation Projects at Orvieto Cathedral. PhD dissertation, New York: Institute of Fine Arts, New York University.

Cambareri Marietta, Roca De Amicis Augusto (2002). Ippolito Scalza. Perugia: Quattroemme.

Chiavoni Emanuela, Paolini Priscilla (a cura di). (2007). Metodi e tecniche integrate di rilevamento per la realizzazione di modelli virtuali dell'architettura e della città. Roma: Gangemi.

D'Amelio Salvatore, Lo Brutto Mauro (2009). Analisi e comparazioni di modelli di superficie di reperti archeologici realizzati tramite laser scanner e fotogrammetria. In Atti della XIII Conferenza Nazionale ASITA, Bari I -4 Dicembre 2009, pp. 84 I-846.

De Luca Livio (20 I I). La fotomodellazione architettonica. Rilievo, modellazione, rappresentazione di edifici a partire da fotografie. Palermo: Dario Flaccovio.

Docci Mario (2005). Metodologie innovative integrate per il rilevamento dell'architettura e dell'ambiente. Roma: Gangemi. Fumi Luigi (|89|). II Duomo di Orvieto e i suoi restauri; monografie storiche condotte sopra i documenti. Roma: Società Laziale tipografica.

Franchetti Pardo Vittorio (20 I 4). La cattedrale di Orvieto: origine e divenire. Scritti editi e inediti. Perugia: Deputazione di Storia Patria per l'Umbria.

Guarnieri Alberto, Remondino Fabio,Vettore Antonio (2004). Photogrammetry and Ground - based laser scanner:Assessment of metric accuracy of the 3D model of Pozzoveggiani Church. In FIG Working Week 2004. TS on Positioning and measurement Technologies and Pratices II - Laser Scanner and Photogrammetry, Atene: <https://fig.net/resources/proceedings/fig_proceedings/ athens/papers/ts26/TS26_4_Guarnieri_et_al.pdf>.

Muratore Giorgio, Loiali Patrizia (2005). Paolo Zampi (I 842-1914). Orvieto: Fondazione Cassa di Risparmio di Orvieto.

Onori Elena (20 I I). Un secolo nemico a le Lettere e a l'Arti ti tolse lo splendore de 'I tuo bel manto antico. II Duomo di Orvieto: fucina delle arti dopo il Concilio di Trento. In Bollettino Istituto Storico Artistico Orvietano, LXVII, pp. 2 I 5-236.

Remondino Fabio, El-Hakim Sabry (2006). Image-based 3D modeling: a review. In The Photogrammetric Record Journal, 2 I , I I 5 , pp. 269-291.

Riccetti Lucio (a cura di). (1988). II Duomo di Orvieto. Roma-Bari: Laterza. 
Satolli Alberto (1978). Documentazione inedita sugli interventi cinquecenteschi nel duomo scomparsi con i restauri del 1877 , in appendice a ID., Quel bene detto duomo. In Bollettino Istituto Storico Artistico Orvietano, XXXIV, pp. I29- 160.

Tosini Patrizia (20 I0). II Duomo di Orvieto nella seconda metà del Cinquecento: un modello per la pittura della Controriforma. In Benocci Carla, Della Fina Giuseppe, Fratini Corrado (a cura di). Storia di Orvieto. Pisa: Pacini.

Zampi Paolo ( 1889 ). Notizie sui lavori di restauro eseguiti per la copertura del Duomo di Orvieto. In L'Ingegneria civile e le arti industriali, XV, pp. 5-29.

\section{Authors}

Roberto Barni, Sapienza Università di Roma, roberto.barni@hotmail.it

Carlo Bianchini, Sapienza Università di Roma, carlo.bianchini@uniromal .it

Carlo Inglese, Sapienza Università di Roma, carlo.inglese@uniromal.it

To cite this chapter. Barni Roberto, Bianchini Carlo, Inglese Carlo (2020). II duomo di Orvieto. Rilievo integrato e modellazione/The Cathedra of Orvieto. Integrated Survey and Modeling. In Arena A., Arena M., Brandolino R.G., Colistra D., Ginex G., Mediati D., Nucifora S., Raffa P. (a cura di). Connettere. Un disegno per annodare e tessere. Atti del $42^{\circ}$ Convegno Internazionale dei Docenti delle Discipline della Rappresentazione Connecting. Drawing for weaving relationships. Proceedings of the 42th International Conference of Representation Disciplines Teachers. Milano: FrancoAngeli, pp. 1678-1699. 